\title{
Mapping Water Quality Parameters with Sentinel-3 Ocean and Land Colour Instrument Imagery in the Baltic Sea
}

\author{
Kaire Toming ${ }^{1,2,3} \mathbb{B}^{(\mathbb{B}}$, Tiit Kutser ${ }^{1, *}$, Rivo Uiboupin ${ }^{4}$, Age Arikas ${ }^{4}$, Kaimo Vahter ${ }^{4}$ \\ and Birgot Paavel ${ }^{1}$ \\ 1 Estonian Marine Institute, University of Tartu, Mäealuse 14, 12618 Tallinn, Estonia; \\ Kaire.Toming.001@ut.ee (K.T.); Birgot.Paavel@ut.ee (B.P.) \\ 2 Centre for Limnology, Estonian University of Life Sciences, Kreutzwaldi 5, 51014 Tartu, Estonia \\ 3 Department of Ecology and Genetics/Limnology, Uppsala University, Norbyvägen 18D, \\ 75236 Uppsala, Sweden \\ 4 Department of Marine Systems, School of Science, Tallinn University of Technology, Akadeemia Road 15a, \\ 12618 Tallinn, Estonia; Rivo.Uiboupin@ttu.ee (R.U.); age.arikas@ttu.ee (A.A.); kaimo.vahter@msi.ttu.ee (K.V.) \\ * Correspondence: Tiit.Kutser@ut.ee; Tel.: +372-6718-947
}

Received: 2 August 2017; Accepted: 12 October 2017; Published: 20 October 2017

\begin{abstract}
The launch of Ocean and Land Colour Instrument (OLCI) on board Sentinel-3A in 2016 is the beginning of a new era in long time, continuous, high frequency water quality monitoring of coastal waters. Therefore, there is a strong need to validate the OLCI products to be sure that the technical capabilities provided will be used in the best possible way in water quality monitoring and research. The Baltic Sea is an optically complex waterbody where many ocean colour products, performing well in other waterbodies, fail. We tested the performance of standard Case-2 Regional/Coast Colour (C2RCC) processing chain in retrieving water reflectance, inherent optical properties (IOPs), and water quality parameters such as chlorophyll $a$, total suspended matter (TSM) and coloured dissolved organic matter (CDOM) in the Baltic Sea. The reflectance spectra produced by the C2RCC are realistic in both shape and magnitude. However, the IOPs, and consequently the water quality parameters estimated by the C2RCC, did not have correlation with in situ data. On the other hand, some tested empirical remote sensing algorithms performed well in retrieving chlorophyll $a, \mathrm{TSM}, \mathrm{CDOM}$ and Secchi depth from the reflectance produced by the C2RCC. This suggests that the atmospheric correction part of the processor performs relatively well while IOP retrieval part of the neural network needs extensive training with actual IOP data before it can produce reasonable estimates for the Baltic Sea.
\end{abstract}

Keywords: OLCI; Sentinel-3; Baltic Sea; C2RCC

\section{Introduction}

The launch of Ocean and Land Colour Instrument (OLCI) on board ESA Sentinel-3A satellite in February 2016 and the planned near future launch of identical sensor on Sentinel-3B opened a new era in coastal water remote sensing. Previous ocean colour sensors (Sea-Viewing Wide Field-of-View Sensor (SeaWiFS); Moderate Resolution Imaging Spectroradiometer (MODIS); and MEdium Resolution Imaging Spectrometer (MERIS)) were one-off scientific missions not designed for water quality monitoring. Sentinel satellites, launched in the Copernicus program, are designed to provide continuous long-term data flow to allow monitoring of environmental parameters with high accuracy enabling not only operational monitoring but also studies on environmental change. OLCI is a follow up of MERIS mission (2002-2012) with improved capabilities. Its spectral configuration is specifically 
designed for optically complex coastal and inland waters, i.e., it has spectral bands in red and near-infrared (NIR) part of spectrum where most of the useful spectral information, needed to retrieve different water quality parameters, is situated [1-8].

The Baltic Sea is an extraordinarily complex study object for ocean colour remote sensing. High amount of coloured dissolved organic matter (CDOM) received from boreal forest in the catchment area makes the water dark. This means that the water leaving signal is very low requiring highly sensitive remote sensing devices and very accurate atmospheric correction (typically more than $95 \%$ of the signal measured by satellites originates from atmosphere not water). In addition, sun elevation is low during most of the year. Low salinity (down to 0 Practical Salinity Unit (psu) in some parts) and high latitudes are the cause why large portion of the Baltic Sea is covered by ice in winter. There are two distinct phytoplankton seasons in the Baltic Sea [9]. Diatoms dominate the spring bloom that occurs after ice melt and cyanobacteria dominate during summer and early autumn. Optical properties of these two assemblages are so different that seasonal remote sensing algorithms may be needed $[10,11]$. There are also indications that the seasonality is changing $[12,13]$.

The optical complexity of the Baltic Sea is probably one of the reasons why Copernicus Marine Environment Monitoring Services (CMEMS) have not managed to develop ocean colour products that perform reasonably well. For example, the correlation between CMEMS chlorophyll $a$ product and in situ data is $r^{2}=0.20$ [14] while for some wavelengths of the reflectance products $r^{2}$ is around 0.5 . The neural network used to retrieve chlorophyll $a$ and reflectance products first estimates inherent optical water properties (IOPs) such as the total absorption coefficient, the absorption coefficients of pigments, detritus and CDOM, and the particulate backscattering, which are then used to calculate derived products (such as the chlorophyll $a$, total suspended matter, Secchi depth, etc.). These products are provided at the global scale and for some regional seas, but not for the Baltic Sea. Therefore, it is not possible to validate the CMEMS IOP products and there is need to find other methods to retrieve water quality parameters in the Baltic Sea.

Estimation of the phytoplankton biomass (usually expressed as chlorophyll $a$ concentration) is especially complicated in the Baltic Sea during cyanobacterial season when blooms may cover area of more than 200,000 $\mathrm{km}^{2}$ [15]. Cyanobacteria, unlike most phytoplankton, can regulate their buoyancy and in calm conditions (wind below $2 \mathrm{~m} \mathrm{~s}^{-1}$ ) choose the depth optimal for their growth. Vertical distribution of the biomass has significant impact on the measured reflectance [16] and consequently our ability to estimate cyanobacterial biomass. Moreover, cyanobacteria that have lost their buoyancy control form surface scum that may be several centimetres thick. It is not possible to estimate the biomass within the scum as the thickness cannot be estimated and the amount of still alive cells (chlorophyll a) may be significantly lower on the surface of the scum (due to photodegradation) than inside of it. Obviously, it is not possible to estimate phytoplankton biomass below the opaque scum. It has been shown that the cyanobacterial blooms are extremely heterogeneous and chlorophyll $a$ may vary by three orders of magnitude within one OLCI pixel [4]. This causes problems in algorithm development and validation. First of all, the in situ sample collected with typical point measurement does not represent the same situation satellites are detecting. In addition, the reflectance measured by satellite does not represent the actual situation. For example, pixel that is partially covered with surface scum (high NIR reflectance, similar to terrestrial plants) and partially with relatively clear water below (negligible reflectance in NIR) is often detected as subsurface bloom (peak between 700-710 nm) [4].

Despite the above-mentioned complexity, studies demonstrate reasonable performance of remote sensing, at least at regional scales and/or in open parts of the Baltic Sea. Different remote sensing products (chlorophyll $a$, CDOM, suspended matter, diffuse attenuation coefficient, etc.) have been developed or adopted for the Baltic Sea [3,4,6,8,11,17-28]. Many of the recent studies rely on MERIS data and the results can probably be implemented on Sentinel-3 OLCI data as well. The aim of this study was to test the performance of Sentinel-3A OLCI in coastal waters of the Baltic Sea by evaluating the results of atmospheric correction, ocean colour products produced by the standard processor 
(C2RCC) and selected empirical algorithms that have shown promising results in the Baltic Sea when applied on other sensors or modelled data.

\section{Materials and Methods}

\subsection{Study Sites and in Situ Data}

In order to compile as many data sources as possible in testing the performance of Sentinel-3 OLCI, we used in situ data from three different sources:

- Field campaigns dedicated for Sentinel-2 and Sentinel-3 validation where bio-optical measurements were carried out from a boat with comprehensive set of optical instrumentation followed by water sample analysis in laboratory (circles on Figure 1).

- Bio-physical sampling campaigns on R/V Salme included both fixed station sampling with limited number of optical measurements (reflectance, IOPs), accompanied with water sampling, and ferrybox measurements between the stations (triangles and lines on Figure 1).

- Reflectance measurements collected for satellite data calibration and validation with Rflex systems [29] on ships of opportunity under the frame of the BONUS FerryScope project (www.ferryscope.org), along with in situ data collected with ferrybox systems (markers in the Southern part of the Baltic Sea).

Three dedicated field campaigns (16 measurements, on 24 May, 14 September, and 12 October 2016) were carried out from a boat. Water samples for the analysis of chlorophyll $a$ (in $\mathrm{mg} \mathrm{m}^{-3}$ ), total suspended matter (TSM, in $\mathrm{mg} \mathrm{L}^{-1}$ ), inorganic fraction of suspended matter (SPIM, in $\mathrm{mg} \mathrm{L}^{-1}$ ), the organic fraction of suspended matter (SPOM, in $\mathrm{mg} \mathrm{L}^{-1}$ ) and $a_{\mathrm{CDOM}}\left(\right.$ in $^{-1}$ ) were collected from surface layer (top $0.5 \mathrm{~m}$ ). Besides the water sampling, in situ data collection included reflectance measurements (described in Section 2.2), spectral absorption, attenuation, scattering and backscattering measurements (WetLabs AC-S, ECO-vsf3, ECO-bb3, Philomath, OR, USA), volume scattering at three angles and three wavelengths (WetLabs ECO-vsf3, Philomath, OR, USA), CTD (SeaBird, Philomath, OR, USA) data collection and fluorometric measurements of chlorophyll $a$, phycocyanin and CDOM (Trios, microFLU, Oldenburg, Germany).

Two ship cruises were conducted using the vessel R/V Salme (17 measurements, on 26 July and 3 August) in 2016. Reflectance measurements (described in Section 2.2) were carried out in fixed stations together with water sampling from surface layer (top $0.5 \mathrm{~m}$ ) for the analysis of chlorophyll $a$ (in $\mathrm{mg} \mathrm{m}^{-3}$ ) and total suspended matter (TSM, in $\mathrm{mg} \mathrm{L}^{-1}$ ). In addition, spectral absorption and attenuation in the wavelength range from $402 \mathrm{~nm}$ to $732 \mathrm{~nm}$ were measured at each station using AC-S instrument (WetLabs, Philomath, OR, USA).

A ferrybox system (by GO-Systemelektronik BlueBox-System) installed on board the R/V Salme collected data at $2 \mathrm{~m}$ depth between the fixed sampling stations (822 measurements on $26 \mathrm{July}$; 1088 measurements on 3 August 2016). During the cruises, water was pumped continuously through measuring system equipped with fluorometers for chlorophyll $a$ (in $\mathrm{mg} \mathrm{m}^{-3}$ ), phycocyanin (ppb), and turbidity (NTU, ECO Fluorometers, WetLabs, Philomath, OR, USA). Measurements, together with GPS signal, were logged by BlueBox-system at $60 \mathrm{~s}$ frequency, giving a spatial resolution of about $250 \mathrm{~m}$.

A time series of shipborne remote sensing reflectance (described in Section 2.2), chlorophyll $a$ and turbidity (385 measurements, on 10 May 2016) were collected from the Southern Baltic Sea. This is a subset of data collected in the frame of the FerryScope project [30]. The mean time difference between Sentinel-3 OLCI and in situ data was approximately one day. 


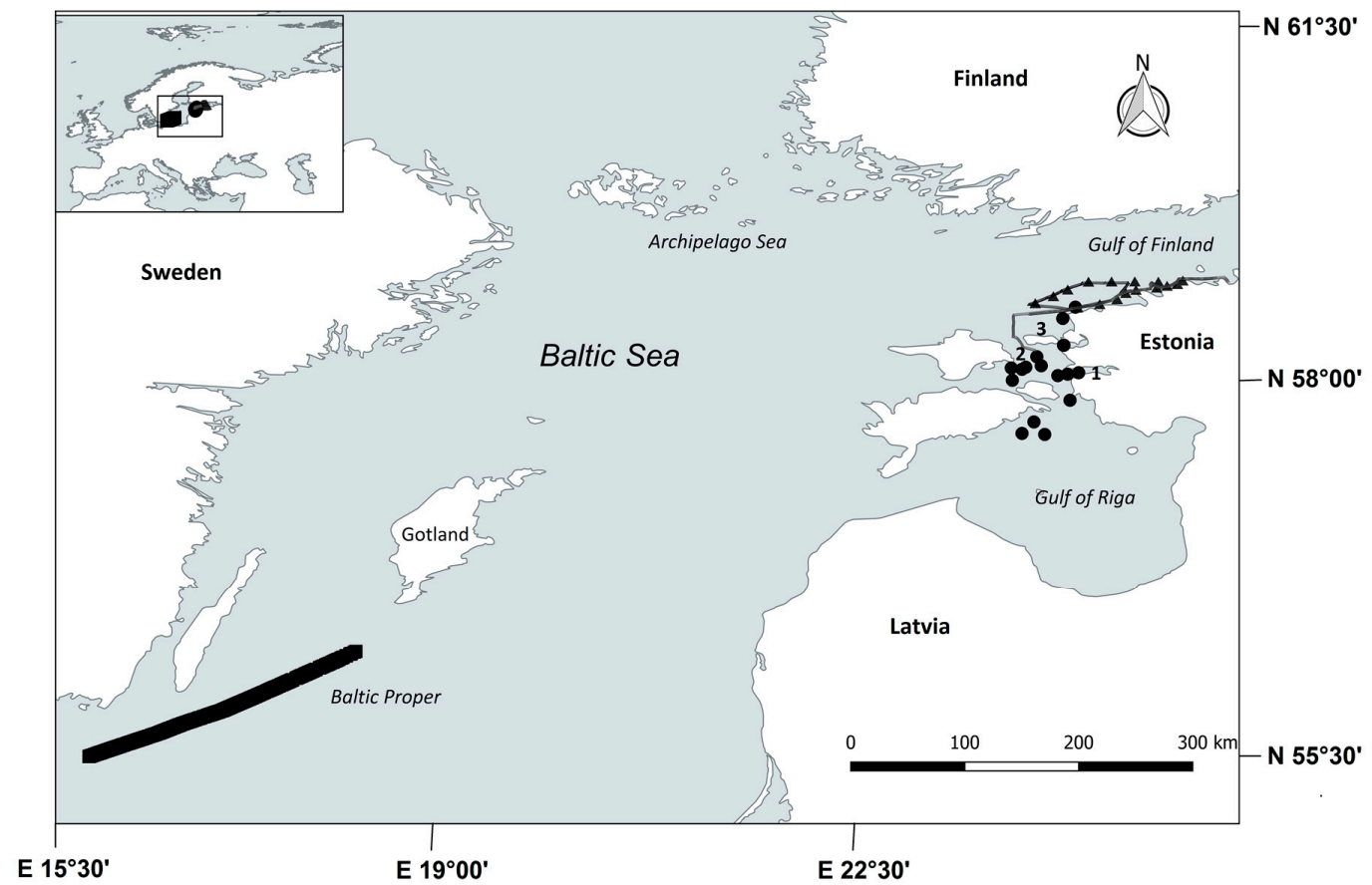

Figure 1. Locations of the sampling points: Squares, FerryScope; circles, boat measurements; triangles, research vessel R/V Salme; rout behind the triangles, R/V Salme ferrybox; 1, Matsalu Bay; 2, Hiiu Strait; and 3, Nordgrund.

Concentration of chlorophyll $a$ was determined by filtering the water samples through Whatman GF/F glass microfibre filters (pore size $0.7 \mu \mathrm{m}$, diameter $47 \mathrm{~mm}$, Whatman International Ltd., Mainstone, UK), extracting the pigments with ethanol (96\%) and spectrophotometrically measuring absorption at wavelengths of $665 \mathrm{~nm}$ and $750 \mathrm{~nm}$ [31]. The values of chlorophyll $a$ were calculated with the Lorenzen formula [32].

The concentration of TSM, was measured gravimetrically after filtration of the same amount of water through pre-weighed and pre-combusted $\left(103-105^{\circ} \mathrm{C}\right.$ for $\left.1 \mathrm{~h}\right) \mathrm{GF} / \mathrm{F}$ filters. The increase of filter weight indicates TSM concentration in the water sample. The inorganic fraction of suspended matter (SPIM) was measured after combustion at $550{ }^{\circ} \mathrm{C}$ for $30 \mathrm{~min}$. The organic fraction of suspended matter (SPOM) was determined by subtraction of SPIM from TSM (ESS, 1993).

$a_{\mathrm{CDOM}}$ was measured with a spectrometer (Hitachi U-3010 UV/VIS, at the range of 350-750 nm) in water filtered through a Millipore $0.2 \mu \mathrm{m}$ filter. Measurements were carried out in a $5 \mathrm{~cm}$ cuvette against distilled water and corrected for residual scattering according to [33]. $a_{\mathrm{CDOM}}(412)$ was used for measuring CDOM concentration in the algorithm analyses. Different algorithms use different wavelengths for CDOM, but as Kowalczuk et al. [19] has shown, the slope of the CDOM in the Baltic Sea is relatively stable throughout the year so using a different wavelength as reference should not change the performance of the algorithm [11].

Secchi depth was measured from a boat and R/V Salme with a $30 \mathrm{~cm}$ diameter Secchi disk.

\subsection{Reflectance Measurements}

Reflectance measurements used in this study were collected in three different ways: the in situ measurements from a boat were carried out with radiance $\left(L_{u}\right)$ and irradiance $\left(E_{d}\right)$ sensor, the measurements from R/V Salme were performed with an irradiance $\left(E_{d}\right)$ sensor and the measurements from ships of opportunity were carried out with triple radiometer system $\left(L_{u}, L_{d}, E_{d}\right)$.

The boat reflectance measurements were carried out with two TriOS RAMSES sensors, where RAMSES-ACC-VIS measured sky irradiance and RAMSES-ARC upwelling radiance. 
The downwelling irradiance sensor was looking straight up and the upwelling radiance sensor was looking straight down. Reflectance was calculated as $L_{u} / E_{d}$. Reflectance measurements were carried out both in the air and under water. The methodology, which also includes glint-free measurements, was described in more detail in [34]. RAMSES measures with $3.3 \mathrm{~nm}$ spectral interval at the wavelength range of 350-900 $\mathrm{nm}$. In order to avoid errors in reflectance spectra that occur due to the slight wavelength differences between the two sensors, both radiance and irradiance values were interpolated to a 2 -nm step before calculating the reflectance.

The R/V Salme measurements were carried out just below the water surface using a RAMSES-ACC hyperspectral radiometer. The RAMSES used measures with a $3.3 \mathrm{~nm}$ spectral interval at the wavelength range of 305.9-1142.8 $\mathrm{nm}$ (wavelength range from $350 \mathrm{~nm}$ to $900 \mathrm{~nm}$ was used in current analysis). Downwelling $\left(E_{d}\right)$ irradiance was measured when the sensor was looking straight up, upwelling $\left(E_{u}\right)$ irradiance was measured by turning the device face down and measuring at the same height/depth. Irradiance reflectance was calculated as $E_{u} / E_{d}$.

The ship of opportunity reflectance measurements were carried out with Rflex systems [29] that consists of three Ramses sensors and a moving platform with software that keeps the sensor package at optimal viewing angles proposed by [35]. It measures with a $3.3 \mathrm{~nm}$ spectral interval at the wavelength range of 320-947 $\mathrm{nm}$.

\subsection{Sentinel-3 OLCI Data}

Sentinel-3 OLCI full resolution (FR) Level-1 and Level-2 data products with $300 \mathrm{~m}$ spatial resolution were used for analyses. Sentinel-3 OLCI cloud free images were available on 9 May, 21 May, 26 July, 3 August (with system vicarious calibration), 14 September and 10 October (without system vicarious calibration) 2016. Spectral bands of Sentinel-3 OLCI are brought out in Table 1.

Sentinel-3 Toolbox Kit Module (S3TBX) version 5.0.1 in Sentinel Application Platform (SNAP) version 5.0. On Windows 10 was used to process the images. Cloud free pixel values corresponding to the locations of sampling points were extracted from OLCI imagery. To get the Level-1 Top of Atmosphere (TOA) and Level-2 (L2) Bottom of Atmosphere (BOA) reflectance images (derived from the associated L1 products) Case-2 Regional/Coast Colour (C2RCC) atmospheric correction (AC) module version 0.15 for Sentinel-3 OLCI was applied. Output products of the C2RCC are: BOA reflectance, inherent optical properties (absorption coefficient of phytoplankton pigments, detritus, coloured dissolved organic carbon and total absorption at $443 \mathrm{~nm}$, scattering coefficient of marine and white particles at $443 \mathrm{~nm}$ ), chlorophyll, TSM and CDOM, which were compared with appropriate in situ measurements.

Table 1. Spectral bands, central wavelengths (nm) and bandwidths (nm) of Sentinel-3 OLCI.

\begin{tabular}{ccc}
\hline Band Number & Central Wavelength $(\mathbf{n m})$ & Bandwidth $(\mathbf{n m})$ \\
\hline Oa1 & 400 & 15 \\
Oa2 & 412.5 & 10 \\
Oa3 & 442.5 & 10 \\
Oa4 & 490 & 10 \\
Oa5 & 510 & 10 \\
Oa6 & 560 & 10 \\
Oa7 & 620 & 10 \\
Oa8 & 665 & 10 \\
Oa9 & 673.75 & 7.5 \\
Oa10 & 681.25 & 7.5 \\
Oa11 & 708.75 & 10 \\
Oa12 & 753.75 & 7.5 \\
Oa13 & 761.25 & 2.5 \\
Oa14 & 764.375 & 3.75 \\
Oa15 & 767.5 & 2.5 \\
Oa16 & 778.75 & 15 \\
\hline
\end{tabular}


Table 1. Cont.

\begin{tabular}{ccc}
\hline Band Number & Central Wavelength $(\mathbf{n m})$ & Bandwidth $(\mathbf{n m})$ \\
\hline Oa17 & 865 & 20 \\
Oa18 & 885 & 10 \\
Oa19 & 900 & 10 \\
Oa20 & 940 & 20 \\
Oa21 & 1020 & 40 \\
\hline
\end{tabular}

In addition to the standard processor (C2RCC), common empirical algorithms were tested (Table 2).

Table 2. List of empirical algorithms tested in this study.

\begin{tabular}{|c|c|c|}
\hline Algorithm (Wavelength) & Algorithm (OLCI Bands) & Reference \\
\hline \multicolumn{3}{|c|}{ Chlorophyll $a$ and Other Pigments } \\
\hline R560/R665 & B6/B8 & [36] \\
\hline R665/R709 & $\mathrm{B} 8 / \mathrm{B} 11$ & [21] \\
\hline R665/R754 & B8/B12 & \\
\hline R674/R709 & $\mathrm{B} 9 / \mathrm{B} 11$ & [37] \\
\hline R674/R754 & $\mathrm{B} 9 / \mathrm{B} 12$ & \\
\hline R709/R754 & $\mathrm{B} 11 / \mathrm{B} 12$ & {$[38]$} \\
\hline$(1 / R 6651 / R 709) \times R 754$ & $(1 / \mathrm{B} 8-1 / \mathrm{B} 11) \times \mathrm{B} 12$ & [39] \\
\hline$(\mathrm{R} 490-\mathrm{R} 665) / \mathrm{R} 560$ & $(\mathrm{~B} 4-\mathrm{B} 8) / \mathrm{B} 6$ & [40] \\
\hline $\mathrm{R} 709-((\mathrm{R} 665+\mathrm{R} 754) / 2)$ & $\mathrm{B} 11-((\mathrm{B} 8+\mathrm{B} 12) / 2)$ & [41] \\
\hline $\mathrm{R} 709-\mathrm{R} 754$ & $\mathrm{~B} 11-\mathrm{B} 12$ & \\
\hline \multicolumn{3}{|c|}{ Total Suspended Matter } \\
\hline R665/R560 & B8/B6 & [42] \\
\hline R709 & B11 & [43] \\
\hline \multicolumn{3}{|c|}{ Coloured Dissolved Organic Matter } \\
\hline $\mathrm{R} 665 / \mathrm{R} 490$ & $\mathrm{~B} 8 / \mathrm{B} 4$ & [21] \\
\hline \multirow{2}{*}{ R665/R560 } & $\mathrm{B} 8 / \mathrm{B} 6$ & [44] \\
\hline & Secchi & \\
\hline$(\mathrm{R} 560 / \mathrm{R} 709)^{0.788} \times 1.125$ & $(\mathrm{~B} 6 / \mathrm{B} 11)^{0.788} \times 1.125$ (turbid waters) & [45] \\
\hline$(\mathrm{R} 490 / \mathrm{R} 709)^{0.697} \times 2.137$ & $(\mathrm{~B} 4 / \mathrm{B} 11)^{0.697} \times 2.137$ (clear waters) & [45] \\
\hline
\end{tabular}

\section{Results}

\subsection{In Situ Data}

The in situ data used in this study come from three different sources, as described above. Therefore, the number and type of parameters varies. Table 3 summarises the results of the measurements.

The boat measurements included absorption and scattering that are also products of the C2RCC processing chain. The absorption, attenuation and scattering coefficient measurements were hyperspectral and backscattering measurements were carried out at six wavelengths. Some total absorption coefficient spectra are shown in Figure 2 together with data from our other Baltic Sea study sites to demonstrate how the results of this study fit within the range of optical properties we have observed previously. 
Table 3. In situ data of chlorophyll $a(\mathrm{Chl} a)$, phycocyanin, total suspended matter (TSM), the inorganic fraction of suspended matter (SPIM), the organic fraction of suspended matter (SPOM), turbidity, $a_{\mathrm{CDOM}}(412)$, Secchi disc depth (Secchi), total absorption at $443 \mathrm{~nm}\left(a_{\text {tot }}\right)$, total attenuation at $443 \mathrm{~nm}\left(c_{\text {tot }}\right)$, total scattering at $443 \mathrm{~nm}\left(b_{\text {tot }}\right)$, and total backscattering at $470 \mathrm{~nm}\left(b b_{\text {tot }}\right)$ collected during three different field campaigns on 24 May, in on 14 September and on 12 October 2016 (Boat), on board the R/V Salme on 26 July and 3 August 2016 (R/V Salme stations), by Ferrybox installed on board research vessel R/V Salme on 26 July and 3 August 2016 (R/V Salme Ferrybox) and measured in the frame of the FerryScope project on 10 May 2016 (FerryScope).

\begin{tabular}{|c|c|c|c|c|c|c|c|c|c|c|c|c|c|}
\hline & & $\begin{array}{c}\mathrm{Chl} a \\
\left(\mathrm{mg} \mathrm{m}^{-3}\right)\end{array}$ & $\begin{array}{c}\text { Phycocyanin } \\
\text { (ppb) }\end{array}$ & $\begin{array}{c}\text { TSM } \\
\left(\mathrm{mg} \mathrm{L}^{-1}\right)\end{array}$ & $\begin{array}{c}\mathrm{SPIM} \\
\left(\mathrm{mg} \mathrm{m}^{-3}\right)\end{array}$ & $\begin{array}{c}\text { SPOM } \\
\left(\mathrm{mg} \mathrm{m}^{-3}\right)\end{array}$ & $\begin{array}{c}a_{\mathrm{CDOM}}(412) \\
\left(\mathrm{m}^{-1}\right)\end{array}$ & $\begin{array}{c}\text { Turbidity } \\
\text { (NTU) }\end{array}$ & $\begin{array}{l}\text { Secchi } \\
\text { (m) }\end{array}$ & $\begin{array}{c}a_{\text {tot }} \\
\left(m^{-1}\right)\end{array}$ & $\begin{array}{c}c_{\text {tot }} \\
\left(m^{-1}\right)\end{array}$ & $\begin{array}{c}b_{\text {tot }} \\
\left(m^{-1}\right)\end{array}$ & $\begin{array}{l}b b_{\text {tot }} \\
\left(\mathrm{m}^{-1}\right)\end{array}$ \\
\hline \multirow{4}{*}{ Boat } & Mean & 1.53 & 1.52 & 6.83 & 4.94 & 1.90 & 0.99 & - & 5.18 & 0.55 & 1.61 & 1.07 & 0.02 \\
\hline & Min & 0.38 & 0.11 & 4.55 & 2.90 & 0.99 & 0.60 & - & 2.20 & 0.39 & 0.69 & 0.29 & 0.01 \\
\hline & Max & 2.95 & 2.93 & 9.14 & 7.36 & 3.50 & 3.20 & - & 12.7 & 0.80 & 2.33 & 1.76 & 0.05 \\
\hline & $N$ & 17 & 17 & 17 & 17 & 17 & 17 & - & 17 & 15 & 15 & 15 & 15 \\
\hline \multirow{4}{*}{$\begin{array}{l}\text { R/V Salme } \\
\text { stations }\end{array}$} & Mean & 4.33 & 1.14 & 2.23 & - & - & - & - & 3.32 & 0.64 & 2.12 & 1.48 & - \\
\hline & Min & 1.81 & 0.13 & 1.20 & - & - & - & - & 2.50 & 0.58 & 1.84 & 1.2 & - \\
\hline & Max & 6.02 & 1.44 & 4.53 & - & - & - & - & 4.00 & 0.75 & 2.79 & 2.2 & - \\
\hline & $N$ & 16 & 8 & 16 & - & - & - & - & 16 & 16 & 15 & 15 & - \\
\hline \multirow{4}{*}{$\begin{array}{l}\text { R/V Salme } \\
\text { Ferrybox }\end{array}$} & Mean & 1.12 & 0.35 & - & - & - & - & 0.66 & - & - & - & - & - \\
\hline & Min & 0.00 & 0.00 & - & - & - & - & 0.24 & - & - & - & - & - \\
\hline & Max & 2.63 & 1.81 & - & - & - & - & 12.8 & - & - & - & - & - \\
\hline & $N$ & 822 & 299 & - & - & - & - & 771 & - & - & - & - & - \\
\hline \multirow{4}{*}{ FerryScope } & Mean & 1.60 & - & - & - & - & - & 0.29 & - & - & - & - & - \\
\hline & Min & 0.82 & - & - & - & - & - & 0.19 & - & - & - & - & - \\
\hline & Max & 2.48 & - & - & - & - & - & 0.36 & - & - & - & - & - \\
\hline & $N$ & 385 & - & - & - & - & - & 385 & - & - & - & - & - \\
\hline
\end{tabular}




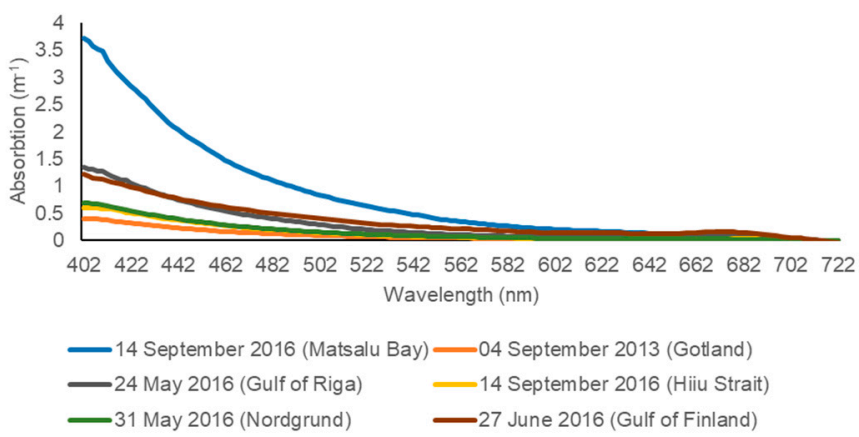

Figure 2. Selected total absorption coefficient spectra of the Baltic Sea. The Gotland spectrum is from our other field study [46] to show typical absorption we have measured in the open parts of the Baltic Sea and Swedish Archipelago waters during our previous field campaigns.

\subsection{Atmospheric Correction and Reflectance Spectra}

In situ reflectance spectra were recalculated into Sentinel-3 OLCI bandwidths and compared with the C2RCC corrected reflectance. The comparison between OLCI bottom of atmosphere reflectance spectra and FerryScope project Rflex system results are shown in Figure 3, with R/V Salme underwater irradiance reflectance in Figure 4 and with glint-free remote sensing reflectance measured from a boat in Figure 5.
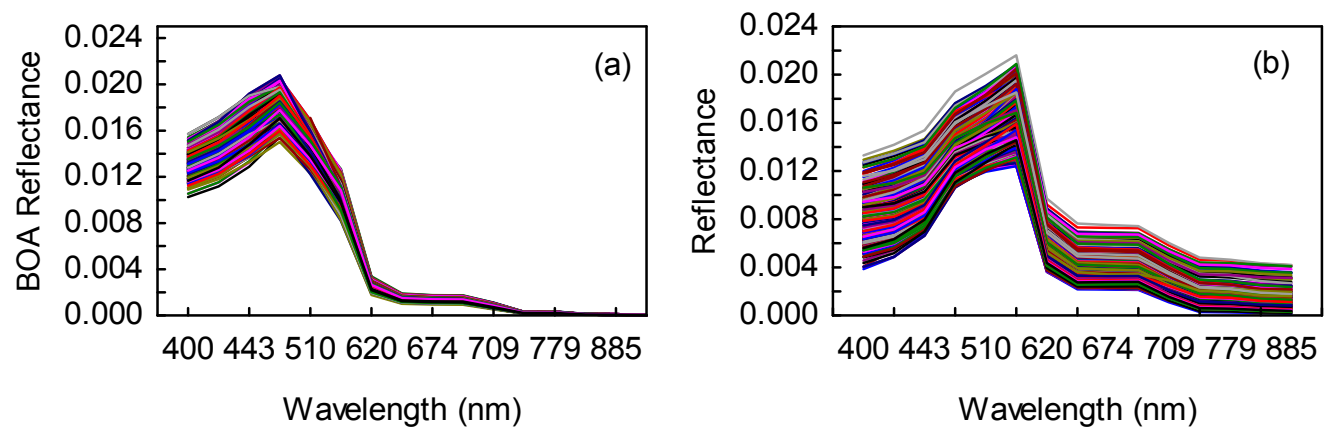

Figure 3. Reflectance spectra of the open Baltic Sea area: (a) Bottom of Atmosphere (BOA) reflectance of Sentinel-3 OLCI after correction with C2RCC (9 May 2010); and (b) FerryScope reflectance spectra measured on 10 May 2016 and recalculated to match Sentinel-3 OLCI bands.
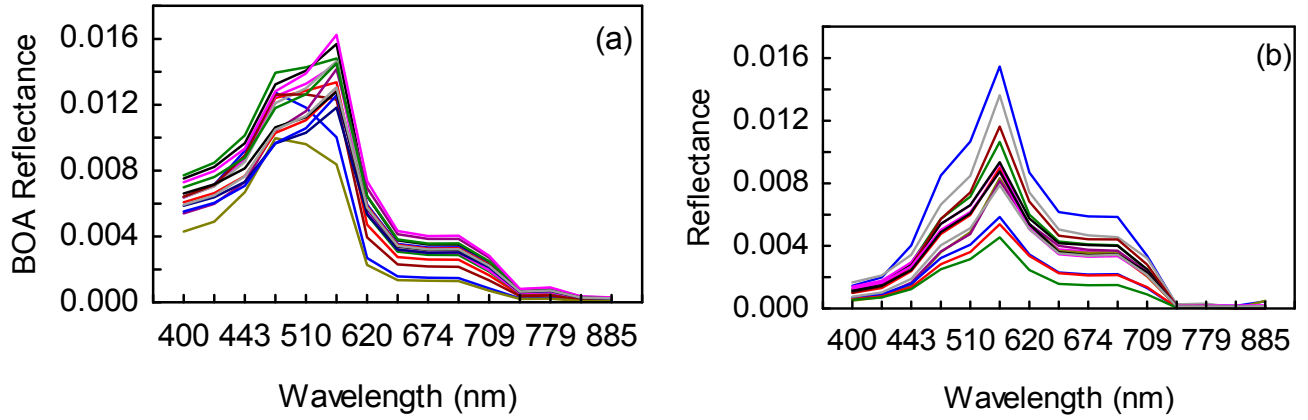

Figure 4. Reflectance spectra of the coastal waters of Baltic Sea: (a) Bottom of Atmosphere (BOA) reflectance of Sentinel-3 OLCI after correction with C2RCC (26 July and 3 August 2016); and (b) $\mathrm{R} / \mathrm{V}$ Salme. Reflectance spectra measured on board the research vessel R/V Salme on 26 July and 3 August 2016 and recalculated into Sentinel-3 bands. 

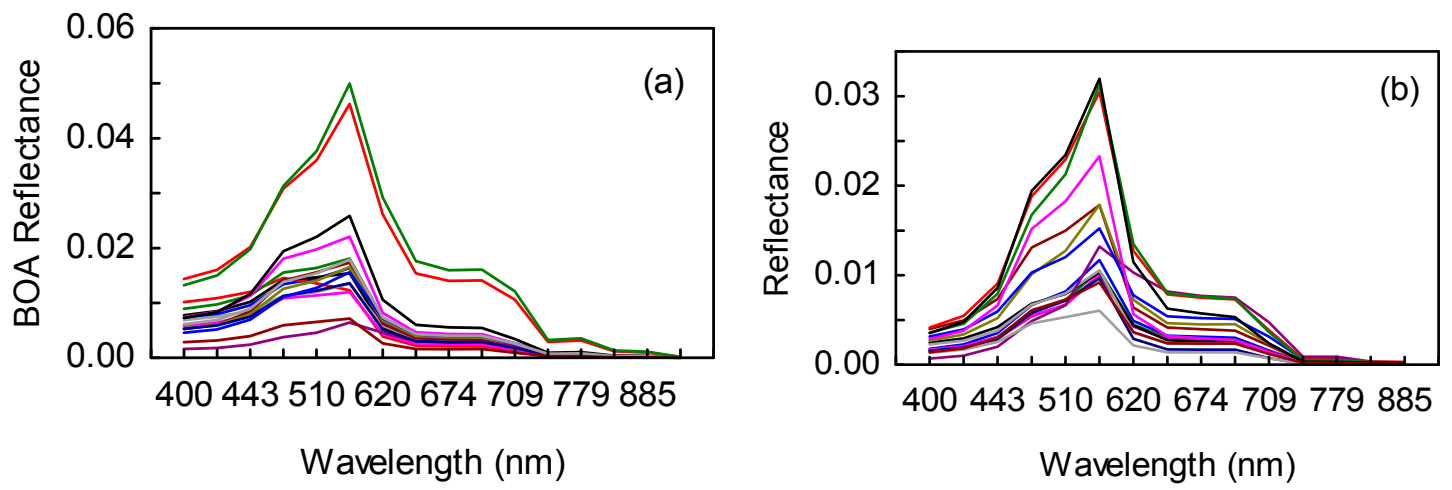

Figure 5. Reflectance spectra of the coastal waters of the Baltic Sea: (a) Bottom of Atmosphere (BOA) reflectance of Sentinel-3 OLCI after correction with C2RCC (21 May, 14 September and 10 October 2016); and (b) boat. Glint-free reflectance spectra measured with the methodology described in [35] during three different field campaigns (24 May, 14 September, 12 October 2016) and recalculated into Sentinel-3 OLCI bands.

We also calculated band by band correlations between the atmospherically corrected OLCI data and three different types of in situ reflectance. The correlation coefficients are given in Table 4.

Table 4. Correlation (and corresponding $p$-values) between bottom of atmosphere (BOA) reflectance of Sentinel-3 OLCI after correction with C2RCC and in situ reflectance. Reasonably good correlations are highlighted in bold. $\mathrm{R}$, correlation coefficient; $P, p$-value.

\begin{tabular}{ccccccc}
\hline \multirow{2}{*}{$\begin{array}{c}\text { Central Wavelength } \\
\text { (nm)/Band }\end{array}$} & \multicolumn{2}{c}{ FerryScope } & R/V Salme & \multicolumn{3}{c}{ Field } \\
\cline { 2 - 7 } & $\mathbf{R}$ & $\mathbf{P}$ & $\mathbf{R}$ & $\boldsymbol{P}$ & $\mathbf{R}$ & $\boldsymbol{P}$ \\
\hline $\mathbf{4 0 0}$ (B1) & 0.06 & 0.25 & $\mathbf{0 . 5 5}$ & 0.03 & $\mathbf{0 . 5 1}$ & 0.04 \\
$\mathbf{4 1 3}$ (B2) & 0.06 & 0.26 & $\mathbf{0 . 5 6}$ & 0.03 & $\mathbf{0 . 5 5}$ & 0.02 \\
$\mathbf{4 4 3}$ (B3) & 0.07 & 0.20 & $\mathbf{0 . 6 6}$ & 0.01 & $\mathbf{0 . 6 7}$ & 0.00 \\
$\mathbf{4 9 0}$ (B4) & $\mathbf{0 . 3 1}$ & 0.00 & $\mathbf{0 . 6 5}$ & 0.01 & $\mathbf{0 . 7 7}$ & 0.00 \\
$\mathbf{5 1 0 ( B 5 )}$ & $\mathbf{0 . 5 9}$ & 0.00 & 0.38 & 0.16 & $\mathbf{0 . 8 1}$ & 0.00 \\
$\mathbf{5 6 0}$ (B6) & $\mathbf{0 . 7 7}$ & 0.00 & -0.16 & 0.58 & $\mathbf{0 . 8 2}$ & 0.00 \\
$\mathbf{6 2 0}$ (B7) & $\mathbf{0 . 7 1}$ & 0.00 & -0.48 & 0.07 & $\mathbf{0 . 7 7}$ & 0.00 \\
$\mathbf{6 6 5}$ (B8) & $\mathbf{0 . 6 8}$ & 0.00 & -0.47 & 0.08 & $\mathbf{0 . 6 8}$ & 0.00 \\
$\mathbf{6 7 4}$ (B9) & $\mathbf{0 . 6 9}$ & 0.00 & -0.49 & 0.06 & $\mathbf{0 . 6 8}$ & 0.00 \\
$\mathbf{6 8 1}$ (B10) & $\mathbf{0 . 6 9}$ & 0.00 & -0.51 & 0.05 & $\mathbf{0 . 6 8}$ & 0.00 \\
$\mathbf{7 0 9}$ (B11) & $\mathbf{0 . 6 4}$ & 0.00 & -0.41 & 0.13 & $\mathbf{0 . 5 8}$ & 0.02 \\
$\mathbf{7 5 4}$ (B12) & $\mathbf{0 . 6 0}$ & 0.00 & -0.18 & 0.51 & 0.43 & 0.09 \\
$\mathbf{7 7 9}$ (B16) & $\mathbf{0 . 6 0}$ & 0.00 & 0.06 & 0.82 & 0.37 & 0.14 \\
$\mathbf{8 6 5}$ (B17) & $\mathbf{0 . 6 0}$ & 0.00 & 0.07 & 0.82 & $\mathbf{0 . 6 1}$ & 0.01 \\
$\mathbf{8 8 5}$ (B18) & $\mathbf{0 . 5 9}$ & 0.00 & -0.63 & 0.01 & $\mathbf{0 . 7 1}$ & 0.00 \\
\hline
\end{tabular}

The height of the peak between 700 and $710 \mathrm{~nm}$ has been used as a proxy of phytoplankton biomass (chlorophyll $a$ ) for a long time [41]. The NIR part of spectrum is also important for detecting surface scum, as was mentioned above [4]. Therefore, the correct representation of the $709 \mathrm{~nm}$ band height and NIR signal are especially important for the Baltic Sea. Our own observations, as well as published results [46], suggest that most atmospheric correction procedures had problems in retrieving the $709 \mathrm{~nm}$ peak properly (compared to in situ data), especially in the earlier phases of MERIS mission. There was dense cyanobacterial bloom slightly outside the R/V Salme route on 26 July 2016 . We chose a few pixels from the image where it was sure that there is at least a very dense subsurface bloom if not surface scum present and checked how the C2RCC performs in such situation. The comparison between TOA and BOA reflectance is given in Figure 6, which indicates that the C2RCC atmospheric correction provides unrealistic reflectance spectra in cyanobacterial bloom situations. 

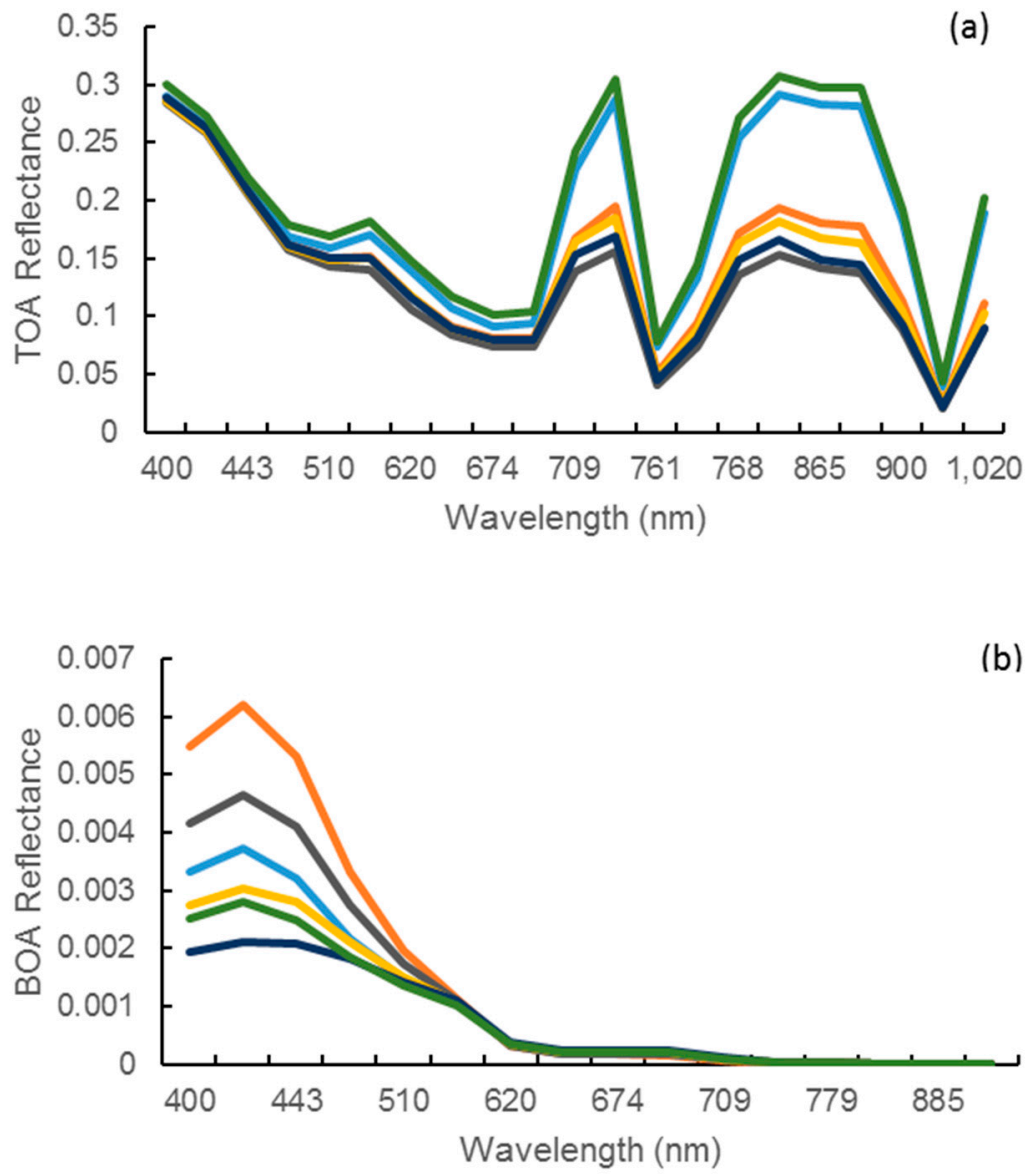

Figure 6. Sentinel-3 OLCI reflectance spectra from the bloom area near the R/V Salme route (26 July 2016): (a) top of atmosphere (TOA) reflectance of OLCI; and (b) bottom of atmosphere (BOA) reflectance of OLCI after correction with C2RCC.

\subsection{Results of the Remote Sensing Products vs. In Situ Data}

The C2RCC processor retrieves first inherent optical properties, such as absorption and scattering coefficients, and then estimates the concentrations of optically active substances from the IOPs. It is seen in Figure 7 that none of the OLCI products had statistically significant correlation $(p>0.05)$ with in situ measured values.
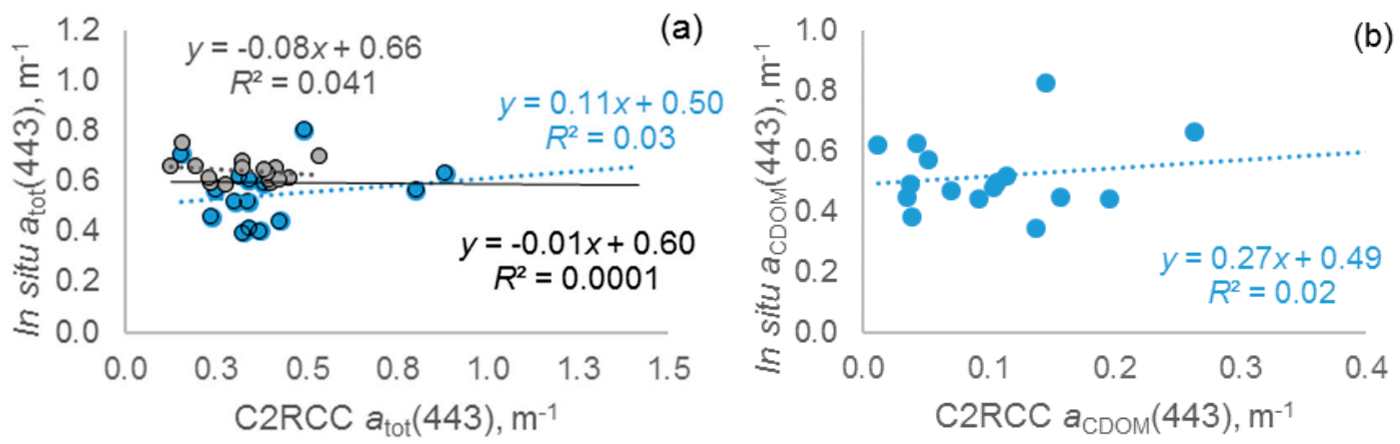

Figure 7. Cont. 

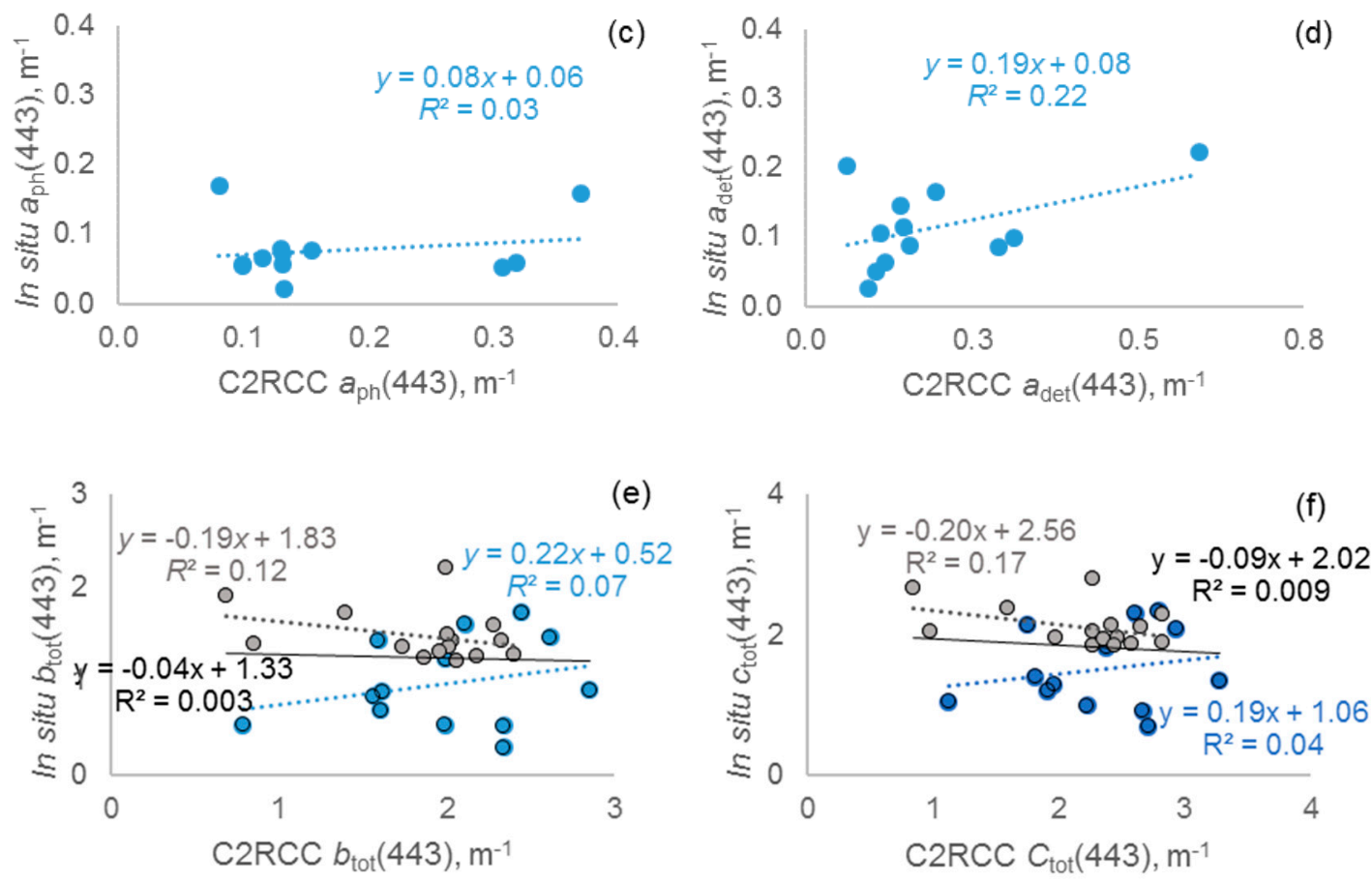

Figure 7. Comparison of inherent optical properties of C2RCC and appropriate in situ measurements: (a) $a_{\mathrm{tot}}(443),(\mathbf{b}) a_{\mathrm{CDOM}}(443),(\mathbf{c}) a_{\mathrm{ph}}(443),(\mathbf{d}) a_{\mathrm{det}}(443),(\mathbf{e}) b_{\mathrm{tot}}(443),(\mathbf{f}) c_{\mathrm{tot}}(443)$. Grey dots, R/V Salme; blue dots, boat; and black regression line, R/V Salme + boat.

OLCI chlorophyll $a$ and TSM products are calculated from estimated IOP values (pigment absorption and total scattering products at $443 \mathrm{~nm}$ respectively). Therefore, it is surprising that the concentration products have slightly better correlation with in situ data than the IOPs they were derived from (Figure $8 a, b)$, although the highest correlation $\left(R^{2}=0.25\right)$ is still very low. The correlations were even higher when we used in situ data collected with ferrybox flow through systems (Figure 8c,d). However, it is clearly seen that the scatter of the results is very high despite the correlation coefficients in the range of 0.4-0.5. For example, C2RCC chlorophyll $a$ varies between 0 and $11 \mathrm{mg} \mathrm{m}^{-3}$ when the ferrybox concentration is around $2.5 \mathrm{mg} \mathrm{m}^{-3}$ and for C2RCC concentrations $6 \mathrm{mg} \mathrm{m}^{-3}$ ferrybox values range between 1.5 and $6 \mathrm{mg} \mathrm{m}^{-3}$ (Figure 8c). It must be noted that there are no in situ IOP data for the points where ferrybox data were collected.
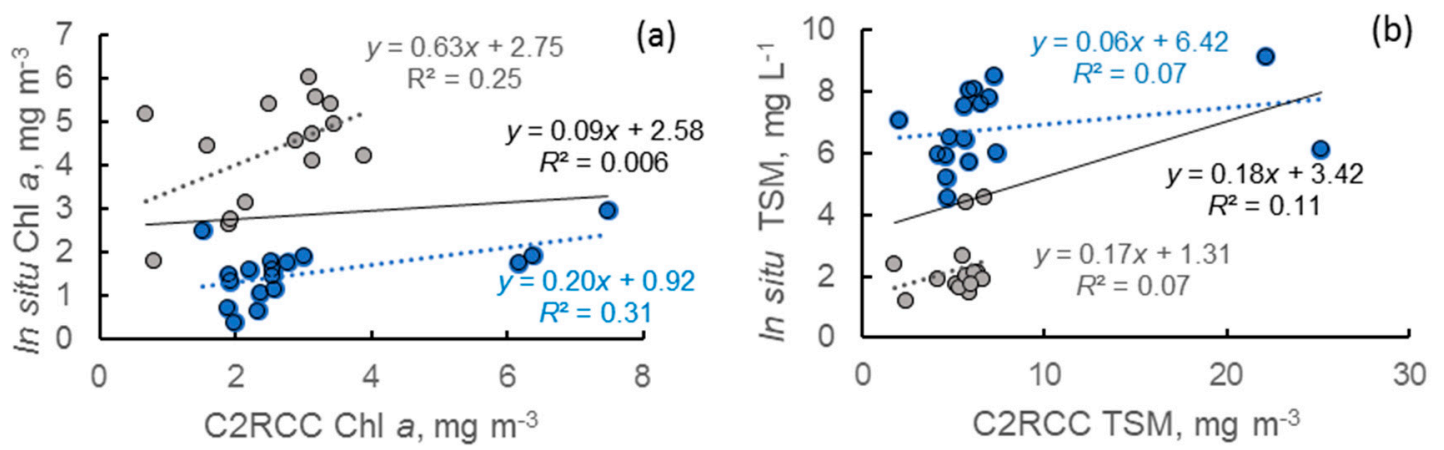

Figure 8. Cont. 

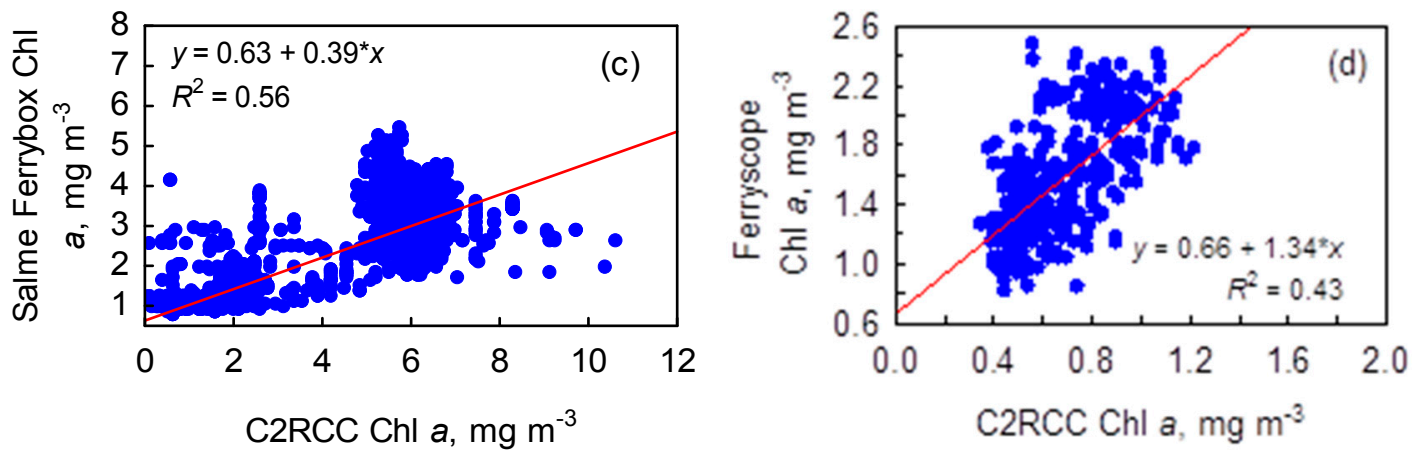

Figure 8. Comparison of output products of C2RCC: (a,c,d) chlorophyll $a(\mathrm{Chl} a)$, and (b) total suspended matter (TSM) and appropriate $(\mathbf{a}, \mathbf{b})$ in situ, (c) R/V Salme ferrybox and (d) FerryScope measurements: (a,b) grey dots, R/V Salme; blue dots, boat; and black regression line, R/V Salme + boat.

\subsection{Results of the Empirical Remote Sensing Algorithms vs. In Situ Data}

The IOPs and concentrations of optically active substances retrieved with the C2RCC processor did not provide reasonable results. On the other hand, reflectance spectra produced by the C2RCC were quite realistic in non-bloom situations both in shape and magnitude (Figures 3-5). Therefore, we decided to test whether simple empirical algorithms perform better than the neural network approach included in the C2RCC. The algorithms used are given in Table 2 and some better results are shown in Figures 9-13.
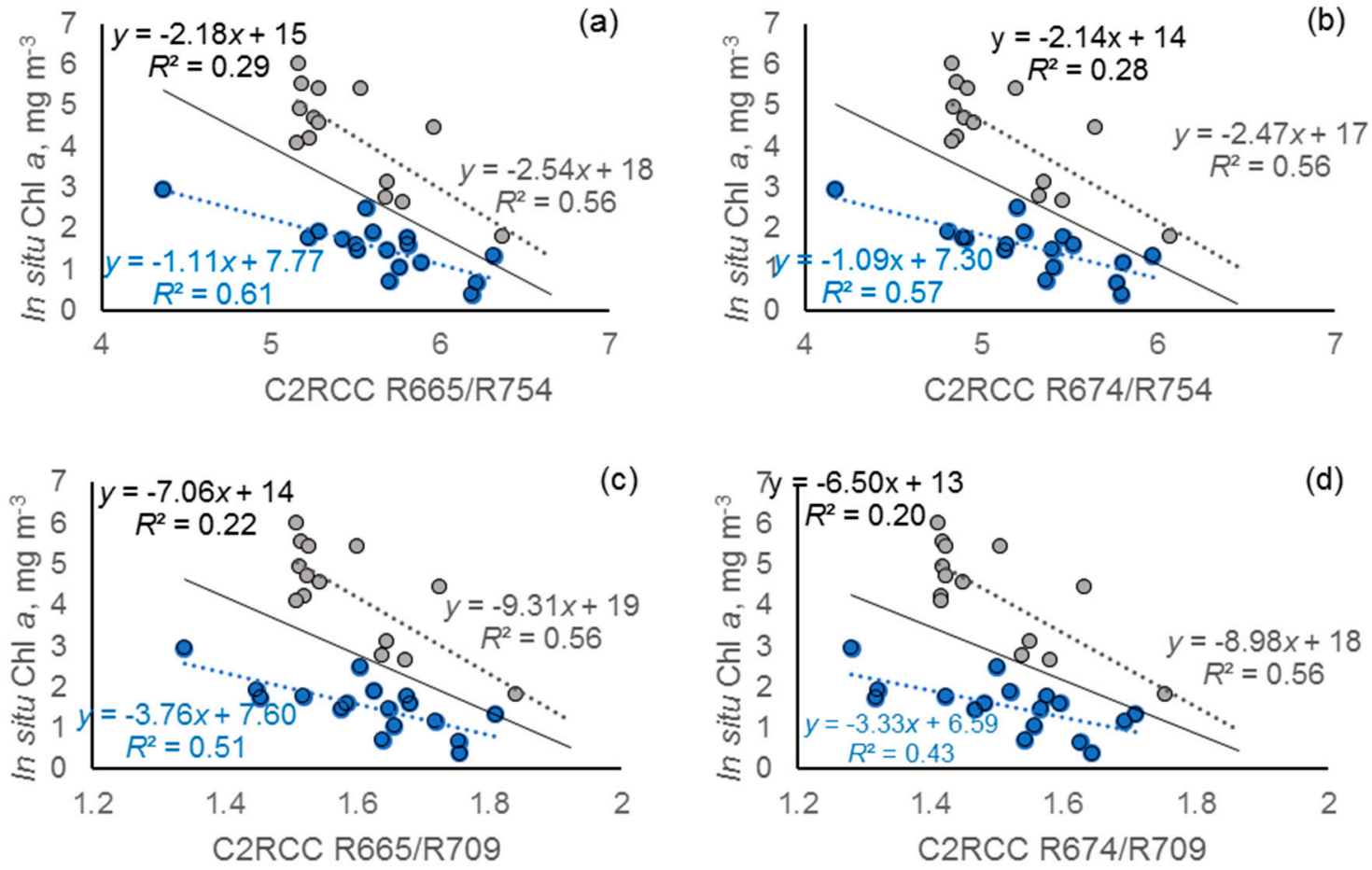

Figure 9. Correlation between the empirical algorithm calculated from the bottom of atmosphere data of Sentinel-3 OLCI (atmospherically corrected with C2RCC) and chlorophyll $a$ (Chl $a$ ): grey dots, $\mathrm{R} / \mathrm{V}$ Salme; blue dots, boat; and black regression line, R/V Salme + boat. 

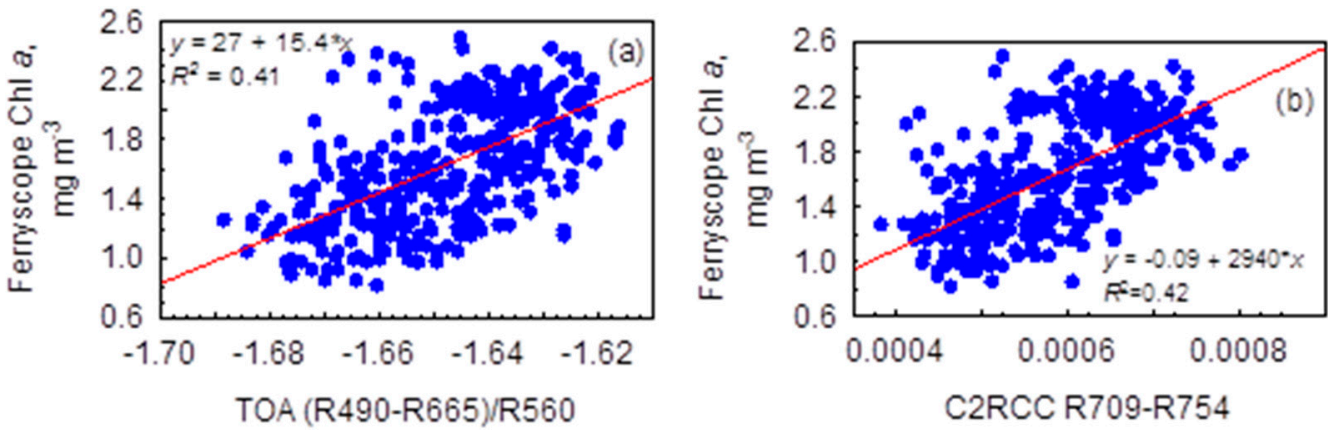

Figure 10. Correlation between the empirical algorithm calculated from the Sentinel-3 OLCI data and chlorophyll $a(\mathrm{Chl} a$ ) measured in the frame of the FerryScope project: (a) empirical algorithm calculated from the top of atmosphere reflectance; and (b) band ratio calculated from the bottom of atmosphere reflectance (atmospherically corrected with C2RCC).
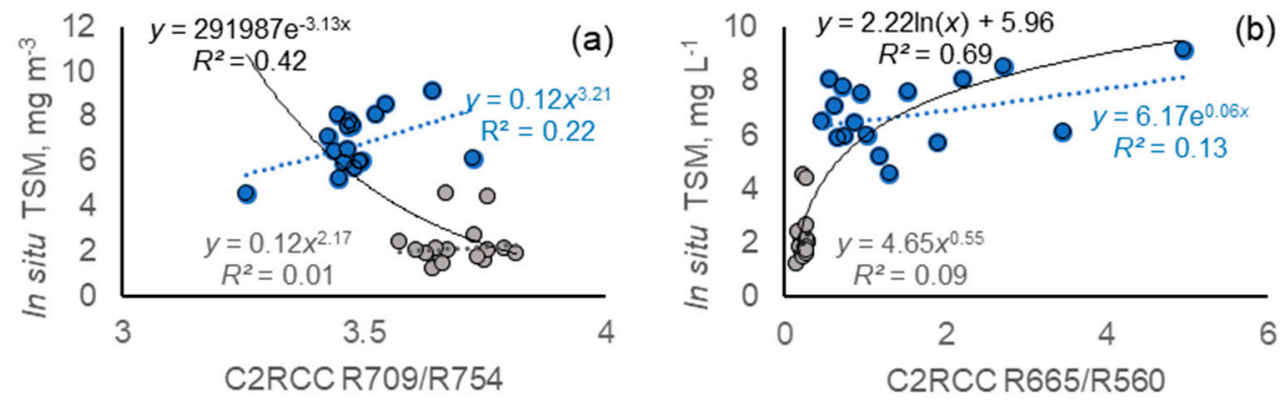

Figure 11. Correlation between the empirical algorithm calculated from the bottom of atmosphere data of Sentinel-3 OLCI (atmospherically corrected with C2RCC) and total suspended matter (TSM): grey dots, R/V Salme; blue dots, boat; and black regression line, R/V Salme + boat.
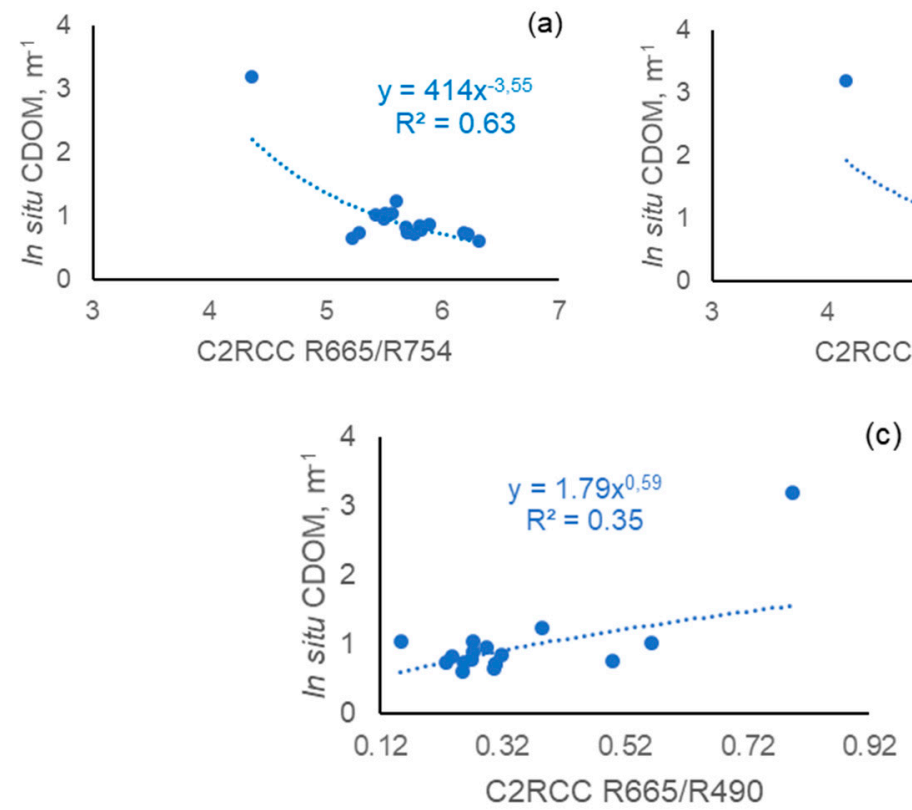

(b)

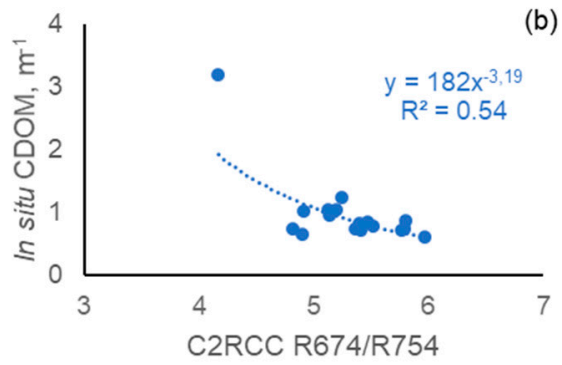

(c)

Figure 12. Correlation between the empirical algorithm calculated from the bottom of atmosphere data of Sentinel-3 OLCI (atmospherically corrected with C2RCC) and coloured dissolved organic matter (CDOM) measured from boat. 

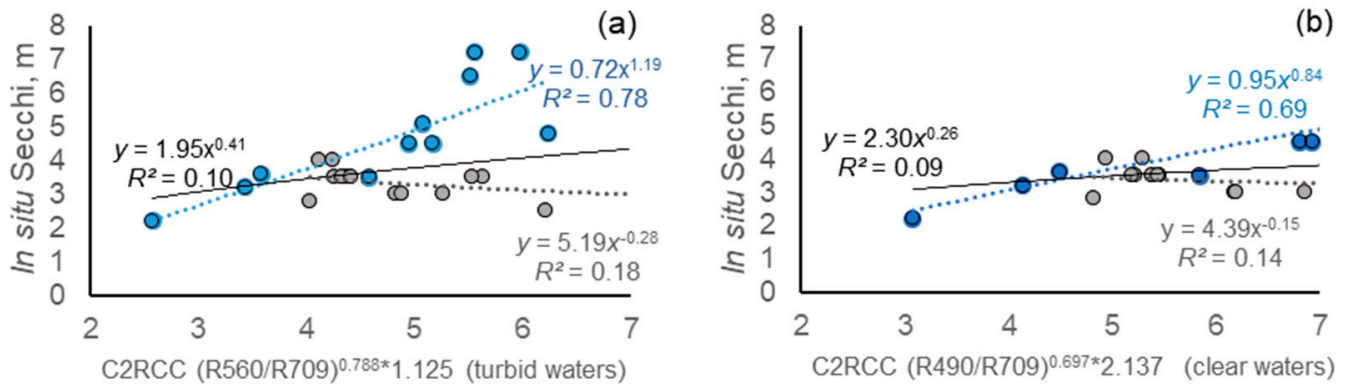

Figure 13. Correlation between the empirical algorithms [45] calculated from the bottom of atmosphere data of Sentinel-3 OLCI (atmospherically corrected with C2RCC) and Secchi disc depth: grey dots, R/V Salme; blue dots, boat; and black regression line, R/V Salme + boat.

\section{Discussion}

Optical properties of the studied waters varied over a quite wide range. Our previous results [46] and the current study (Figure 2) demonstrated that the absorption coefficient varies over an order of magnitude in the coastal waters of the Baltic Sea. Many rocky and relatively deep archipelago waters (e.g., Sweden) are often optically similar to open parts of the Baltic Sea, whereas shallow sandy coastal and archipelago waters (e.g., Estonia and Latvia) are much more absorbing and scattering by resuspended from the sea bottom particles may play significant role in windy days as extensive areas are just a few meters deep. The range of observed absorption coefficients is demonstrated in Figure 2. It is seen that the absorption in the clearest sites was only by about $45-65 \%$ higher than typical central Baltic Sea absorption values. On the other hand, the absorption coefficient was almost by an order of magnitude higher in Matsalu Bay, which is a typical estuary with CDOM-rich inflow from nearby wetlands. Thus, we may say that the study covers a reasonable range of optical variability.

The reflectance spectra produced by C2RCC processing chain from OLCI data for non-bloom conditions are quite reasonable, in both shape and magnitude (Figures 3-5). In the case of Rflex systems on ships of opportunity, the corrected OLCI spectra have too high values in the blue part of spectrum whereas the in situ data has high and variable reflectance in NIR part of spectrum that suggest presence of glint or some other artefact in the reflectances measured from moving ship (Figure 3). Comparison of OLCI reflectance and R/V Salme subsurface irradiance reflectance measurements (Figure 4) also suggest that the BOA OLCI reflectances are too high in blue part of spectrum. The best match between the in situ and OLCI reflectances was observed in the case of boat measurements (Figure 5). It must be noted that the reflectances measured from the boat do not contain any surface reflection (sky and sun glint), as they were measured keeping upwelling radiance sensor just below the water surface [34]. C2RCC is supposed to remove these components from the measured signal as well. Probably, the B1 and B2 values are slightly too high in the OLCI BOA reflectance spectra, but in general the atmospherically corrected spectra are very realistic in non-bloom conditions.

The problems in atmospheric correction are the highest in the blue part of spectrum, as is seen in Figures 3-5 and Table 4. ESA also has ongoing activities to improve OLCI calibration in shorter wavelengths bands, but atmospheric correction of blue bands is very difficult anyway as atmospheric and glint effects are higher in the blue part of spectrum. Water leaving signal in the Baltic Sea is typically close to zero in the blue part of spectrum $[11,25]$ and in coastal waters may be low also at longer wavelengths. This makes atmospheric correction of the Baltic Sea imagery especially difficult. The errors in retrieving correct reflectance do affect results obtained by neural networks as all spectral bands are taken into account in the processing. On the other hand, these errors in both instrument calibration and atmospheric correction do not affect results obtained by means of empirical algorithms as blue wavelengths are not used in empirical algorithms developed for optically complex waters and there are no issues in calibrations and atmospheric correction of green to NIR bands. 
Cyanobacterial blooms cover up to $200,000 \mathrm{~km}^{2}$ of the Baltic Sea every summer [15] and the duration of the blooms may be quite long. Therefore, in the Baltic Sea the performance of any atmospheric correction procedure and water quality retrieval algorithm is especially critical during the cyanobacterial season in the Baltic Sea. The C2RCC atmospheric correction does not provide realistic reflectance in cyanobacterial bloom situations as is seen in Figure 6. The top of atmosphere spectra have significant signal at $709 \mathrm{~nm}$ band (critical for the retrieval of chlorophyll $a$ [42]) and further in NIR part of spectrum (necessary to separate surface scum from dense subsurface bloom). All this useful information is removed by the C2RCC. Ten years ago, there were problems with MERIS atmospheric correction and therefore it was suggested to retrieve chlorophyll $a$ by using the height of the $709 \mathrm{~nm}$ peak taken from the TOA signal instead of BOA [47]. Later atmospheric correction procedures preserved the $709 \mathrm{~nm}$ peak better [48], but still not completely. Thus, the C2RCC has made a step backwards in correcting OLCI data compared to the latest developments in MERIS processing. Some atmospheric correction procedures, such as FLAASH (Fast Line-of-sight Atmospheric Analysis of Hypercubes), produce very realistic subsurface bloom and surface scum reflectance spectra [4]. C2RCC is a neural network approach that requires training data to perform well and produce realistic water reflectances. Thus, there is a strong need for in situ reflectance data from bloom conditions to train the C2RCC processor in order to retrieve realistic reflectance both in the Baltic Sea and large lakes where optically similar blooms do occur. The training data should include surface scum and subsurface blooms with different biomass and different vertical structure as, unlike other types of phytoplankton, cyanobacteria can move in the water column themselves and the vertical distribution of biomass has significant impact on the remote sensing signal [16].

The next step in the C2RCC processing chain, after retrieving water reflectance, is estimating IOPs (absorption and scattering coefficients). For example, the total absorption at $443 \mathrm{~nm}$ is retrieved and is then split into contributions by CDOM, phytoplankton and detritus. Our earlier lake remote sensing studies with MERIS [49] have shown that the total absorption coefficient is retrieved better than its components $\left(a_{\mathrm{ph}}, a_{\mathrm{CDOM}}\right.$, etc.). We measured absorption, scattering and backscattering coefficients during our boat sampling campaigns. Comparisons of the OLCI products with the in situ data showed that the neural network approach used in the C2RCC does not allow yield accurate estimates of IOPs in the Baltic Sea (Figures 7 and 8). Neural networks as such require extensive amount of training data to perform well. The C2RCC processor was trained with simulated reflectance data [50] and was developed to cope better with highly scattering coastal waters such as coccolithophore blooms, which do not occur in the Baltic Sea. However, the Baltic Sea waters in general are highly absorbing $[4,11,25]$ except in very shallow areas with high resuspension during strong wind or some river estuaries that bring higher amount of sediments to the coastal waters. For example, CDOM absorption in several of our sampling sites goes beyond the normal maximum training range of C2RCC. On the other hand, the extreme maximum training range of the C2RCC goes even an order of magnitude higher. Despite that we see no correlation between the measured and estimate from OLCI data IOPs.

It is obvious that the correlations between measured and C2RCC processor estimated water products (chlorophyll $a$, TSM) are close to zero if the retrieved IOPs did not have correlation with in situ values. The best results were obtained when comparing ferrybox data from FerryScope database and the R/V Salme ferrybox measurements with C2RCC chlorophyll (Figure 8). The $\mathrm{r}^{2}$ was up to 0.56 in coastal waters (R/V Salme measurements) and 0.43 in the open parts of the Baltic Sea (FerryScope measurements). This is obviously not satisfactory for any remote sensing product that could be used in quantitative monitoring of phytoplankton biomass not speaking about long time trend studies.

It is seen in the Figure 9 that chlorophyll $a$ estimates made with different empirical algorithms (band ratios) vary for boat sampling and the R/V Salme measurements and the difference is quite consistent for different algorithms. The first potential explanation could be that the C2RCC has some kind of stability problems as the boat and the R/V Salme measurements were made on different dates. However, this cannot be the case, whereas both boat measurements and ship measurements 
were made on multiple dates and the consistency within these two groups of data (boat and ship) is good. Therefore, this difference must come from in situ data. The R/V Salme measurements were carried out during cyanobacterial bloom (July-August), whereas boat measurements were carried out in May, September, and October when other groups of phytoplankton dominated in the water column. Extracting pigments from cyanobacteria is a complicated problem [51]. Consequently, some of the chlorophyll $a$ remains in the cells and is not measured in the spectrophotometer. As a result the measured chlorophyll $a$ values are lower than the actual chlorophyll $a$ concentrations (what remote sensing can detect) in cyanobacterial cells. This should produce the opposite difference between boat and R/V Salme measurements compared to what we observe now.

One of the possible explanations may be differences between the chlorophyll $a$ values obtained in different institutes as problems in the bad performance of C2RCC or dominance of different phytoplankton assemblages should have caused different discrepancies than we observe now. Water samples from R/V Salme and boat cruises were carried out with the same methodology-surface samples were used in both cases. The laboratory methodology used in both institutes is also the same, however, the results we observe are different. Ruling out potential effect of different laboratories would require analysing parallel samples taken from the same stations. This is a topic that needs further analysis.

It is assumed in all remote sensing studies that the in situ values are the "truth" when actually the in situ values have their own errors which may be quite large. HELCOM has carried out intercalibration measurements of chlorophyll $a$ around the Baltic Sea (analysis of water from the same sample) that showed large discrepancies between different institutes. With trainings and further intercalibration experiments, these errors were taken down to $14 \%$ [52]. However, the laboratory analysis error is still quite large. The errors resulting from taking the water samples may be even larger. HELCOM protocol [52] requires taking integral water sample (subsamples taken at different depths are mixed together). This is fine when algae dominate in the phytoplankton community as these are passive particles that are uniformly mixed in the top layer of water (10-20 $\mathrm{m}$ in the Baltic Sea). However, cyanobacteria can regulate their buoyancy and in calm weather (wind less than $2 \mathrm{~m} \mathrm{~s}^{-1}$ ) tend to move to water depth most optimal for their growth. The main biomass of cyanobacteria may be condensed in relatively narrow (a few meters) layer. Thus, it may happen that all subsamples taken for the integral water sample are actually from depths which are very low in cyanobacterial biomass. In that case there is no correlation between the bloom satellites are detecting and the clear water sample analysed in laboratory. On the other hand, one or several subsamples for the integral sample may come from exactly this or these depth(s) where the cyanobacterial bloom was. In that case, the laboratory results will show higher values than remote sensing can detect. During both the boat measurements and R/V Salme measurements all water samples were taken from the surface layer (top $0.5 \mathrm{~m}$ ). Thus, the discrepancies in in situ values due to different sample collection strategies may be ruled out.

The issue of quality of in situ data is one that needs stronger attention. In the situation of general lack of data for algorithm development and validation, remote sensing scientists use whatever is available not knowing how the water samples were collected and how they have been analysed. Using exactly the same sampling and laboratory analysis methodologies can result concentration errors in the order of ten(s) of per cent. On the other hand, differences in sample collection methods and strategies (i.e., sampler type, depth(s), how much care was taken to preserve the natural state of the bloom, etc.) may cause variability in measured biomass that can be in the orders of magnitude. It is obvious that developing and/or validating remote sensing products with such inconsistent data is problematic.

It must be noted that there were no IOP data available for the continuous autonomous measurements of chlorophyll $a$ carried out from moving ships. Therefore, it was not possible to check whether the C2RCC IOP products would have produced reasonable results for the open parts of the Baltic Sea or not. 
It must also be noted that the chlorophyll $a$ fluorometers cannot provide reasonable results when cyanobacteria dominate in water as in cyanobacteria chlorophyll $a$ is in the non-fluorescing photosystem [53]. Meaning that phycocyanin fluorometers have to be used to describe cyanobacterial biomass. R/V Salme cruises were carried out during cyanobacterial bloom, but only in the relatively low biomass edge of the bloom where the biomass of other cells of phytoplankton was probably not very low. Slightly elevated phycocyanin values (up to $1.8 \mathrm{ppb}$ ) were registered by the ferrybox system onboard R/V Salme in the Gulf of Finland while phycocyanin concentration values of $~ 1.2 \mathrm{ppb}$ were observed in the Moonsund (Väinameri) area. It is seen in Figure 10 that scattering of data points is very high despite the relatively high correlation coefficient. For example, if the C2RCC estimate of chlorophyll $a$ is $0.5 \mathrm{mg} \mathrm{m}^{-3}$ then the fluorometer values varied between 0.5 and 4 ; for C2RCC chlorophyll $6 \mathrm{mg} \mathrm{m}^{-3}$ the fluorometer values varied between 1.5 and 6; or for fluorometer values of $3 \mathrm{mg} \mathrm{m}^{-3}$ C2RCC estimated values between 0 and $11 \mathrm{mg} \mathrm{m}^{-3}$. Reflectance spectra produced by the C2RCC were realistic as was shown on Figures 3-5 above. Therefore, it was logical to try simple empirical algorithms in water quality parameter retrieval when C2RCC failed to do this. We did not undertake a full empirical algorithm testing study, as the aim was to test C2RCC as one of the main processors for OLCI data. Nevertheless, several empirical (band ratio) algorithms produced good estimates of chlorophyll $a$, CDOM, TSM, and Secchi depth (Figures 9-12). The result for chlorophyll $a$ retrieval was already described above. As was expected the algorithms utilizing green to red (and NIR) part of spectrum performed the best as the impact of phytoplankton on the blue part of spectrum is usually negligible in CDOM-rich waters such as the Baltic Sea.

Performance of the TSM algorithms was relatively poor. It is not surprising considering that the TSM samples were collected and analysed during the R/V Salme and the boat cruises in near coastal waters. Most of the TSM collected during the R/V Salme measurements were of organic nature (cyanobacterial cells), while boat measurements were carried out in relatively shallow waters, where resuspension of inorganic particles plays significant role, and closer to rivers, which may bring inorganic material into coastal waters. SPIM and SPOM were measured separately only from the boat cruises data and the dominance of inorganic particles is seen also in the Table 3.

Unfortunately, there was only one sampling station where the CDOM value was relatively high compared to the majority of sampled values. Therefore, the conclusion about the performance of CDOM retrieval algorithms using C2RCC corrected OLCI data is not very strong. However, the single high value $\left(3.2 \mathrm{~m}^{-1}\right)$ of this study is not very high for the coastal parts of the Baltic Sea. In our recent study [11], we had $a_{\mathrm{CDOM}}(412)$ rage between $0.28 \mathrm{~m}^{-1}$ and $13.46 \mathrm{~m}^{-1}$. Satellite estimates [54] have shown that CDOM absorption may go over $30 \mathrm{~m}^{-1}$ near some rivers bringing highly absorbing waters from wetlands. Nevertheless, the regression equations that are heavily influenced by one data-point should be used with caution.

OLCI Secchi depth estimates showed also some dependency on the source of in situ data. There may be differences in Secchi depth estimates between measurements carried out from an altitude of a few meters (research vessel) or from a boat (observer a meter or two above the water surface). However, most of the discrepancies between the two data sources seem to come from the fact that the Secchi depth varied very little during R/V Salme measurements while it was varying significantly during the boat measurements.

The results of the study showed that there is strong need in developing the Baltic-Sea-specific C2RCC processor. The current one provides reasonable reflectance results in non-bloom conditions, but fails in cyanobacterial blooms while the IOP and other products do not have correlation with in situ data. On the other hand, there is also strong need in improving the consistency of in situ data used in calibration and validation of satellite data products. Usually, it is assumed that in situ data are the truth against which satellite products are validated. It must be remembered that the in situ data also (even if measured with the same methods, such as chlorophyll $a$ analysis in the lab) have errors that are relatively large. We combined reflectance from different sources measured using three different methods and analysis performed in different laboratories. Our study showed that this had also had 
an effect on the results. Comparing point measurements with large ( $300 \mathrm{~m})$ pixel values is problematic in coastal waters and in cyanobacterial blooms where dramatic changes in water properties occur at meter scales. Combining this with the methodological problems and measurement errors of in situ data described above makes improving remote sensing products extremely difficult.

\section{Conclusions}

Combining the BOA reflectance spectra obtained by means of C2RCC processor with the in situ reflectance spectra shows that the atmospheric correction part of the neural network performs quite well in non-bloom conditions. In the case of dense subsurface blooms and surface scum of cyanobacteria, the atmospheric correction removes the most valuable piece of information-signal at wavelengths longer than $700 \mathrm{~nm}$.

Several empirical algorithms using green to NIR part of spectrum performed relatively well in retrieval of different water quality parameters. This also suggests that the performance of atmospheric correction part of the C2RCC is robust for this part of spectrum.

No correlation between measured and retrieved IOPs was observed. Consequently, there was also no correlation between the retrieved parameters (such as chlorophyll $a$ ) and in situ data. To a certain degree, this result may have been caused by the suboptimal performance of atmospheric correction at shorter wavelengths, as the neural network uses all spectral bands not just green to NIR part like the empirical algorithms. However, the main problem is that the C2RCC is not trained with sufficient amount of data from the Baltic Sea. Significantly more in situ data from different parts of the Baltic Sea collected during different seasons are needed to train the neural network and produce reasonable IOP estimates for the Baltic Sea.

The data collection and analysis methodology may also need improvement in order to develop robust remote sensing products that perform well in optically complex waters. Horizontal, vertical and temporal variabilities of water properties, especially during cyanobacterial blooms or near river estuaries make it challenging to acquire reliable in situ data. Intercalibration of laboratory methods between different institutions is advisable to ensure validation of satellite products against data with well characterized accuracy.

Acknowledgments: The research was supported by the Estonian Research Council (grant No. PUTJD659) and the Estonian Ministry of Education and Research (IUT 21-02, SF0180009s11, and IUT 19-6). FerryScope data were provided by FerryScope project and SYKE. We are grateful to Centre for Limnology, Estonian University of Life Sciences for the help with the laboratory analyses. The authors are grateful to Nelli Rünk for her help with Salme ferrybox data preprocessing and quality check. We are grateful to two anonymous reviewers and the editors for their comments, which greatly improved the manuscript.

Author Contributions: Kaire Toming was responsible for processing and analysing Sentinel-3 OLCI imagery and statistical analyses. Kaire Toming and Tiit Kutser wrote the bulk of the manuscript with input from all co-authors. Rivo Uiboupin, Age Arikas and Kaimo Vahter participated in the fieldwork and carried out the laboratory analysis of data collected on board the R/V Salme, and enhanced the manuscript. Birgot Paavel measured and processed the boat data.

Conflicts of Interest: The authors declare no conflict of interest.

\section{References}

1. Gitelson, A.; Keydan, G.; Shishkin, V. Inland waters quality assessment from satellite data in visible range of the spectrum. Sov. Remote Sens. 1985, 6, 28-36.

2. Schalles, J.F.; Schiebe, F.R.; Starks, P.J.; Troeger, W.W. Estimation of algal and suspended sediment loads (singly and combined) using hyperspectral sensors and experiments. In Proceedings of the Fourth International Conference on Remote Sensing of Marine and Coastal Environments, Orlando, FL, USA, 17-19 March 1997; pp. 247-258.

3. Darecki, M.; Stramski, D. An evaluation of MODIS and SeaWIFS bio-optical algorithms in the Baltic Sea. Remote Sens. Environ. 2004, 89, 326-350. [CrossRef] 
4. Kutser, T. Quantitative detection of chlorophyll in cyanobacterial blooms by satellite remote sensing. Limnol. Oceanogr. 2004, 49, 2179-2189. [CrossRef]

5. Kutser, T.; Metsamaa, L.; Strombeck, N.; Vahtmae, E. Monitoring cyanobacterial blooms by satellite remote sensing. Estuar. Coast. Shelf Sci. 2006, 67, 303-312. [CrossRef]

6. Reinart, A.; Kutser, T. Comparison of different satellite sensors in detecting cyanobacterial bloom events in the Baltic Sea. Remote Sens. Environ. 2006, 102, 74-85. [CrossRef]

7. Paavel, B.; Arst, H.; Metsamaa, L.; Toming, K.; Reinart, A. Optical investigations of CDOM-rich coastal waters in Parnu Bay. Estonian J. Earth Sci. 2011, 60, 102-112. [CrossRef]

8. Alikas, K.; Kratzer, S.; Reinart, A.; Kauer, T.; Paavel, B. Robust remote sensing algorithms to derive the diffuse attenuation coefficient for lakes and coastal waters. Limnol. Oceanogr. Methods 2015, 13, 402-415. [CrossRef]

9. Wasmund, N. Phytoplankton periodicity in a eutrophic coastal water of the Baltic Sea. Int. Rev. Gesamten Hydrobiol. 1994, 79, 259-285. [CrossRef]

10. Simis, S.G.H.; Ylöstalo, P.; Kallio, K.; Spilling, K.; Kutser, T. Contrasting seasonality in optical-biogeochemical properties of the Baltic Sea. PLoS ONE 2017, 12, e0173357. [CrossRef] [PubMed]

11. Ligi, M.; Kutser, T.; Kallio, K.; Attila, J.; Koponen, S.; Paavel, B.; Soomets, T.; Reinart, A. Testing the performance of empirical remote sensing algorithms in the Baltic Sea waters with modelled and in situ reflectance data. Oceanologia 2017, 59, 57-68. [CrossRef]

12. Kahru, M.; Elmgren, R.; Savchuk, O.P. Changing seasonality of the Baltic Sea. Biogeosciences 2016, 13, 1009-1018. [CrossRef]

13. Groetsch, P.M.M.; Simis, S.G.H.; Eleveld, M.A. Spring blooms in the Baltic Sea have weakened but lengthened from 2000 to 2014. Biogeosciences 2016, 13, 4959-4973. [CrossRef]

14. The Copernicus Marine Environment Monitoring Service (CMEMS). Ocean Colour BALTIC Observation Products; Quality information document; EU Copernicus Marine Service: Brussels, Belgium, 2016.

15. Kahru, M.; Elmgren, R. Multidecadal time series of satellite-detected accumulations of cyanobacteria in the Baltic Sea. Biogeosciences 2014, 11, 3619-3633. [CrossRef]

16. Kutser, T.; Metsamaa, L.; Dekker, A.G. Influence of the vertical distribution of cyanobacteria in the water column on the remote sensing signal. Estuar. Coast. Shelf Sci. 2008, 78, 649-654. [CrossRef]

17. Kahru, M.; Horstmann, U.; Rud, O. Satellite detection of increased cyanobacteria blooms in the Baltic Sea-Natural fluctuation or ecosystem change. AMBIO 1994, 23, 469-472.

18. Arst, H.; Kutser, T. Data processing and interpretation of sea radiance factor measurements. Polar Res. 1994, 13, 3-12. [CrossRef]

19. Kowalczuk, P.; Olszewski, J.; Darecki, M.; Kaczmarek, S. Empirical relationships between coloured dissolved organic matter (CDOM) absorption and apparent optical properties in Baltic Sea waters. Int. J. Remote Sens. 2005, 26, 345-370. [CrossRef]

20. Kowalczuk, P.; Zablocka, M.; Sagan, S.; Kuliński, K. Fluorescence measured in situ as a proxy of CDOM absorption and DOC concentration in the Baltic Sea. Oceanologia 2010, 52, 431-471. [CrossRef]

21. Koponen, S.; Attila, J.; Pulliainen, J.; Kallio, K.; Pyhälahti, T.; Lindfors, A.; Rasmus, K.; Hallikainen, M. A case study of airborne and satellite remote sensing of a spring bloom event in the Gulf of Finland. Cont. Shelf Res. 2007, 27, 228-244. [CrossRef]

22. Attila, J.; Koponen, S.; Kallio, K.; Lindfors, A.; Kaitala, S.; Ylöstalo, P. MERIS Case II water processor comparison on coastal sites of the northern Baltic Sea. Remote Sens. Environ. 2013, 128, 138-149. [CrossRef]

23. Harvey, E.T.; Kratzer, S.; Philipson, P. Satellite-based water quality monitoring for improved spatial and temporal retrieval of chlorophyll $a$ in coastal waters. Remote Sens. Environ. 2015, 158, 417-430. [CrossRef]

24. Wozniak, S.B.; Darecki, M.; Zablocka, M.; Burska, D.; Dera, J. New simple statistical formulas for estimating surface concentrations of suspended particulate matter (SPM) and particulate organic carbon (POC) from remote-sensing reflectance in the southern Baltic Sea. Oceanologia 2016, 58, 161-175. [CrossRef]

25. Wozniak, M.; Bradtke, K.M.; Darecki, M.; Krężel, A. Empirical Model for Phycocyanin Concentration Estimation as an Indicator of Cyanobacterial Bloom in the Optically Complex Coastal Waters of the Baltic Sea. Remote Sens. 2016, 8, 212. [CrossRef]

26. Soja-Wozniak, M.; Craig, S.E.; Kratzer, S.; Wojtasiewicz, B.; Darecki, M.; Jones, C.T. A Novel Statistical Approach for Ocean Colour Estimation of Inherent Optical Properties and Cyanobacteria Abundance in Optically Complex Waters. Remote Sens. 2017, 9, 343. [CrossRef] 
27. Kari, E.; Kratzer, S.; Beltran-Abaunza, J.M.; Harvey, T.E.; Vaičiūte, D. Retrieval of suspended particulate matter from turbidity-Model development, validation, and application to MERIS data over the Baltic Sea. Int. J. Remote Sens. 2017, 38, 1983-2003. [CrossRef]

28. Raag, L.; Sipelgas, L.; Uiboupin, R. Analysis of natural background and dredging-induced changes in TSM concentration from MERIS images near commercial harbours in the Estonian coastal sea. Int. J. Remote Sens. 2014, 35, 6764-6780. [CrossRef]

29. Simis, S.G.; Olsson, J. Unattended processing of shipborne hyperspectral reflectance measurements. Remote Sens. Environ. 2013, 135, 202-212. [CrossRef]

30. Kervinen, M.; Simis, S.G.H.; Keto, V.; Boettcher, M. Rflex WFS API Reference, FerryScope D1.2, Version 1.0; Finish Environment Institute: Helsinki, Finland, 2015. Available online: http:/ / ferryscope.org/wp-content/ uploads/2014/10/FerryScope-D1.2-RflexAPIQuickStart-v1.0.4.pdf (accessed on 19 October 2017).

31. Lorenzen, C.J. Determination of chlorophyll and phaeopigments: Spectrophotometric equations. Limnol. Oceanogr. 1967, 12, 343-346. [CrossRef]

32. HELCOM. Helcom Combine-Manual for Marine Monitoring in the COMBINE Programme of HELCOM; HELCOM: Helsinki, Finland, 2015.

33. Davies-Colley, R.J.; Vant, W.N. Absorption of light by yellow substance in freshwater lakes. Limnol. Oceanogr. 1987, 32, 416-425.

34. Kutser, T.; Vahtmäe, E.; Paavel, B.; Kauer, T. Removing glint effects from field radiometry data measured in optically complex coastal and inland waters. Remote Sens. Environ. 2013, 133, 85-89. [CrossRef]

35. Mobley, C.D. Estimation of the remote-sensing reflectance from above-surface measurements. Appl. Opt. 1999, 38, 7442-7455. [CrossRef] [PubMed]

36. Kallio, K.; Attila, J.; Härmä, P.; Koponen, S.; Pulliainen, J.; Hyytiäinen, U.-M.; Pyhälahti, T. Landsat ETM+ images in the estimation of seasonal lake water quality in boreal river basins. Environ. Manag. 2008, 42, 511-522. [CrossRef] [PubMed]

37. Kallio, K.; Koponen, S.; Pulliainen, J. Feasibility of airborne imaging spectrometry for lake monitoring-A case study of spatial chlorophyll $a$ distribution in two meso-eutrophic lakes. Int. J. Remote Sens. 2003, 24, 3771-3790. [CrossRef]

38. Moses, W.J.; Gitelson, A.A.; Berdnikov, S.; Povaznyy, V. Estimation of chlorophyll-a concentration in case II waters using MODIS and MERIS data-Successes and challenges. Environ. Res. Lett. 2009, 4, 4. [CrossRef]

39. Zimba, P.V.; Gitelson, A. Remote estimation of chlorophyll concentration in hypereutrophic aquatic systems: Model tuning and accuracy optimization. Aquaculture 2006, 256, 272-286. [CrossRef]

40. Mayo, M.; Gitelson, A.; Yacobi, Y.Z.; Ben-Avraham, Z. Chlorophyll distribution in Lake Kinneret determined from Landsat Thematic Mapper data. Int. J. Remote Sens. 1995, 16, 175-182. [CrossRef]

41. Gitelson, A.A. The peak near $700 \mathrm{~nm}$ on radiance spectra of algae and water: Relationships of its magnitude and position with chlorophyll concentration. Int. J. Remote Sens. 1992, 13, 3367-3373. [CrossRef]

42. Wang, F.; Han, L.; Kung, H.T.; Van Arsdale, R.B. Applications of Landsat-5 TM imagery in assessing and mapping water quality in Reelfoot Lake, Tennessee. Int. J. Remote Sens. 2006, 27, 5269-5283. [CrossRef]

43. Kallio, K.; Kutser, T.; Hannonen, T.; Koponen, S.; Pulliainen, J.; Vepsäläinen, J.; Pyhälahti, T. Retrieval of water quality from airborne imaging spectrometry of various lake types in different seasons. Sci. Total Environ. 2001, 268, 59-77. [CrossRef]

44. Kutser, T.; Pierson, D.C.; Kallio, K.; Reinart, A.; Sobek, S. Mapping lake CDOM by satellite remote sensing. Remote Sens. Environ. 2005, 94, 535-540. [CrossRef]

45. Alikas, K.; Kratzer, S. Improved retrieval of Secchi depth for optically-complex waters using remote sensing data. Ecol. Indic. 2017, 77, 218-227. [CrossRef]

46. Ligi, M.; Kutser, T.; Paavel, B.; Uudeberg, K.; Reinart, A.; Soomets, T.; Vahtmäe, E. 2017 Variability of the optical properties of the Baltic Sea coastal waters. Boreal Environ. Res. 2017, submitted.

47. Jaelani, L.M.; Matsushita, B.; Yanga, W.; Fukushima, T. Evaluation of four MERIS atmospheric correction algorithms in Lake Kasumigaura, Japan. Int. J. Remote Sens. 2013, 34, 8967-8985. [CrossRef]

48. Gower, J.; King, S.; Borstad, G.; Brown, L. The importance of a band at $709 \mathrm{~nm}$ for interpreting water-leaving spectral radiance. Can. J. Remote Sens. 2008, 34, 287-295.

49. Kutser, T.; Verpoorter, C.; Paavel, B.; Tranvik, L.J. Estimating lake carbon fractions from remote sensing data. Remote Sens. Environ. 2015, 157, 138-146. [CrossRef] 
50. Brockmann, C.; Doerffer, R.; Peters, M.; Stelzer, K.; Embacher, S.; Ruescas, A. Evolution of the C2RCC neural network for Sentinel 2 and 3 for the retrieval of ocean colour products in normal and extreme optically complex waters. In Proceedings of the ESA Living Planet, Prague, Czech Republic, 9-13 May 2016.

51. Simis, S.G.H.; Ruiz-Verdu, A.; Antonio Dominguez-Gomez, J.; Pena-Martinez, R.; Peters, S.W.M.; Gons, H.J. Influence of phytoplankton pigment composition on remote sensing of cyanobacterial biomass. Remote Sens. Environ. 2007, 106, 414-427. [CrossRef]

52. HELCOM. Guidelines for Monitoring of Chlorophyll a; HELCOM: Helsinki, Finland, 2017.

53. Raateoja, M.; Seppala, J.; Ylostalo, P. Fast repetition rate fluorometry is not applicable to studies of filamentous cyanobacteria from the Baltic Sea. Limnol. Oceanogr. 2004, 49, 1006-1012. [CrossRef]

54. Kutser, T.; Paavel, B.; Metsamaa, L.; Vahtmäe, E. Mapping coloured dissolved organic matter concentration in coastal waters. Int. J. Remote Sens. 2009, 30, 5843-5849. [CrossRef]

(C) 2017 by the authors. Licensee MDPI, Basel, Switzerland. This article is an open access article distributed under the terms and conditions of the Creative Commons Attribution (CC BY) license (http://creativecommons.org/licenses/by/4.0/). 